\title{
Bifidobacterium cuniculi, Bifidobacterium choerinum, Bifidobacterium boum, and Bifidobacterium pseudocatenulatum: Four New Species and Their Deoxyribonucleic Acid Homology Relationships
}

\author{
V. SCARDOVI, L. D. TROVATELLI, B. BIAVATI, AND G. ZANI \\ Istituto di Microbiologia Agraria, Università di Bologna, Bologna, Italy
}

\begin{abstract}
Among the several thousand bifidobacteria of our collection, 244 strains from the feces of rabbits and suckling pigs, the rumen of cattle, the feces of breast- and bottle-fed infants, the feces of calves, and from sewage are recognized by means of deoxyribonucleic acid (DNA)-DNA hybridization (competition filter method) as belonging to four new, distinct DNA homology groups. Twenty reference DNA preparations from the type strains of the currently known species or from reference strains of the homology groups of Bifidobacterium were used for comparison. The phenotypic traits which distinguish these four groups from previously described species of the genus Bifidobacterium include gross morphology, fermentation characteristics, guanine plus cytosine content of the DNA, the interpeptide bridge of the cell-wall peptidoglycan, and the transaldolase and 6-phosphogluconate dehydrogenase isozyme pattern (by starch gel electrophoresis). The four groups are named and described as new species of the genus Bifidobacterium: B. cuniculi, B. choerinum, B. boum, and B. pseudocatenulatum. The type strains of these species are RA93 (=ATCC 27916), SU806 (=A'TCC 27686), RU917 (=ATCC 27917), and B1279 (=ATCC 27919), respectively.
\end{abstract}

Several species and provisional groups of bifidobacteria isolated from the feces of adult rabbits have been named and described $(17,20,24)$. One of the provisional groups was referred to by Trovatelli et al. (24) as deoxyribonucleic acid (DNA) homology group II. In the present study, this group of bifidobacteria, here referred to as the cuniculi DNA homology group, is described in detail and is recognized as a new species.

Bifidobacteria from the feces of piglets were isolated and studied by Zani et al. (26). Most of the strains were identified on the basis of DNA homology relationships as members of Bifidobacterium suis, B. thermophilum, B. globosum, or B. pseudolongum. These authors also reported that 13 of 95 strains examined were distinct from previously described species. This group was designated homology group coirinense. A few fermentation characteristics and the DNA homology relationships to other organisms from this habitat were reported (26), but the taxonomic status of this group was not established. In the present work, this group, referred to here as the choerinum DNA homology group, is also described and recognized as a new species.

The rumen is an important habitat of bifidobacteria, especially when the animals are fed carbohydrate-rich diets (25). Indeed, isolates from sheep rumen were used for our first studies on the fructose 6-phosphate shunt mechanism of glucose degradation by bifidobacteria (15). Species reported from this habitat include $B$. globosum and $B$. ruminale. $B$. ruminale was found to be identical with $B$. thermophilum, a species isolated by Mitsuoka (6) from the feces of swine. Other bifidobacteria from the rumen (strains RU276, RU348, and RU354) at first appeared to be variants of $B$. ruminale (ref. 18 , p. 290) with a distinct morphology (ref. 18, Fig. 3 to 5 , p. 282); later their DNA relatedness to $B$. thermophilum P16-6 (and B. ruminale RU326) was found to be nearly $70 \%$ (ref. 19 , Table 10 , p. 292). In recent investigations on the effect of diet on the bifidobacteria of the calf rumen, additional isolates were studied by DNA-DNA hybridization. Most of the isolates were members of B. globosum or B. thermophilum (B. ruminale); others (RU917, RU928, RU929, and RU930) were distinct from these species and formed homology group IV, which was rather closely related to $B$. thermophilum. DNA homologies between strains of group IV and strains of $B$. thermophilum ranged from 55 to $75 \%$ (25). From a survey of 460 strains not previously studied by means of DNA-DNA hybridization, including rumen isolates and strains from the feces of piglets (homology group III of Zani et 
TABLE 1. List of isolates studied

\begin{tabular}{lcc}
\hline Isolates & Source & $\begin{array}{c}\text { Culture received } \\
\text { from }\end{array}$ \\
\hline
\end{tabular}

Bifidobacterium cuniculi sp. nov.

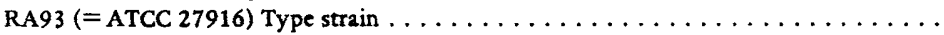

RA94;RA95/ ${ }^{2}$ RA98;RA99/RA104;RA105 VT398;VT399;VT401:VT404/VT405;VT406;VT409

Isolates from sewage (starch positive; formerly assigned to $B$. catenulatum; see ref. 12 ,

Table 1, p. 7):

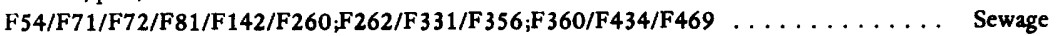

Bifidobacterium catenulatum Scardovi and Crociani

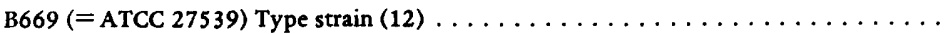

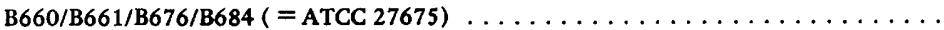

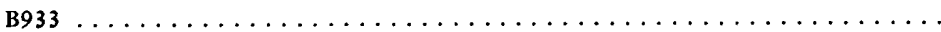
B1331;B1333;B1334;B1 338;B1340;B1341/B1738;B1741;B1742;B1744;B1745;B1746 .. $\mathrm{B} 1748 / \mathrm{B} 1955 / \mathrm{B} 2120 ; \mathrm{B} 2121 ; \mathrm{B2122} ; \mathrm{B} 2123 ; \mathrm{B} 2124 ; \mathrm{B} 2125 ; \mathrm{B} 2126 ; \mathrm{B} 2127 ; \mathrm{B} 2128 \ldots \ldots$ $\mathrm{B} 2130 / \mathrm{B} 2218 / \mathrm{B} 2238 ; \mathrm{B} 2241 ; \mathrm{B} 2242 ; \mathrm{B} 2243 ; \mathrm{B} 2244 ; \mathrm{B} 2245 / \mathrm{B} 2316 / \mathrm{B} 2415 ; \mathrm{B} 2416 ; \mathrm{B} 2417$. B2418;B2419

Isolates from sewage (starch negative; see ref. 12, Table 1, p. 7)

F94/F216;F217/F257;F261/F276/F286/F320;F324/F364/F457 ..........

Bifidobacterium boum sp. nov.

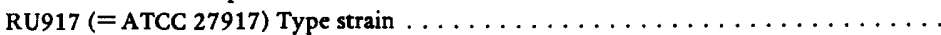
RU246/RU276;RU277/RU289/RU312;RU313/RU315;RU318/RU331/RU334/RU339 . RU341/RU346;RU347/RU358/RU395/RU397/RU400;RU403/RU447/RU473/RU518/ RU590/RU608/RU616;RU617/RU627/RU663;RU664;RU665/RU683/RU888/RU928/ RU929;RU930 . . . . . . . . . . . . . . . . . . . . . SU865/SU873/SU910;SU911;SU912 (unassigned Homology Group III, see ref.26) . . . .

Bifidobacterium thermopbilum Mitsuoka (syn. B. ruminale Scardovi et al.) P2-91 ( = ATCC 25525) Type strain (6); P16-6; 14-44; Nissin $\ldots \ldots \ldots \ldots \ldots \ldots$ RU326 ( $=$ ATCC 25866) Type strain of $B$. ruminale (18) $\ldots \ldots \ldots \ldots \ldots \ldots$ RU301/RU303;RU306/RU325/RU333/RU349;RU350;RU351/RU363;RU364;RU365/ RU366;RU367/RU368/RU398/RU402/RU408/RU409/RU417;RU419/RU424/RU426/. RU430;RU433/RU439/RU458/RU466/RU470/RU471/RU502/RU516/RU562/RU564; RU568;RU569/RU571/RU629/RU647/RU648/RU671;RU673;RU675/RU699/RU718; . RU725;RU733/RU766/RU780;RU782/RU788;RU790/RU792/RU891;RU892;RU893/ . RU894;RU895/RU897;RU899 . . . . . . . . . . . . . . . . . . . . F50/F146/F150/F333;F334/F386/F438;F440;F442;F443;F445/F451;F452/F454 ... F456/F460;F466/F489/F491;F493;F494;F499/F523;F524;F534;F536/F539 $\ldots \ldots$.
Rabbit feces Rabbit feces

Infant feces Infant feces Infant feces Infant feces Infant feces Infant feces Infant feces Infant feces Infant feces Infant feces Calf feces Calf feces Calf feces Calf feces Calf feces Calf feces Calf feces

Our collection

Our collection

Our collection Our collection Our collection Our collection Our collection Our collection Our collection Our collection Our collection Our collection Our collection Our collection Our collection Our collection Our collection Our collection Our collection

Our collection

Adult feces Adult feces Human vagina Infant feces Infant feces Infant feces Infant feces

Our collection Our collection Our collection Our collection Our collection Our collection Our collection

Sewage

Our collection

Bovine rumen Bovine rumen Bovine rumen Bovine rumen Bovine rumen Piglet feces

Piglet feces Bovine rumen Bovine rumen Bovine rumen Bovine rumen Bovine rumen Bovine rumen Bovine rumen Sewage Sewage
Our collection Our collection Our collection Our collection Our collection Our collection

\section{T. Mitsuoka ${ }^{c}$} Our collection Our collection Our collection Our collection Our collection Our collection Our collection Our collection Our collection

${ }^{a}$ Shills (/) separate different specimens from which isolates were obtained.

${ }^{b}$ The cultures were received in 1970 from G. Reuter, Institut für Lebensmittelhygiene, Freie Universität, Berlin. Since then they have been maintained in our collection.

c The cultures were received in 1970 from T. Mitsuoka, Institute of Physical and Chemical Research; Yamato-

Machi, Saitama, Japan. Since then they have been maintained in our collection.

${ }^{d}$ The underlined isolates were used as additional references. 
TABLE 1. continued

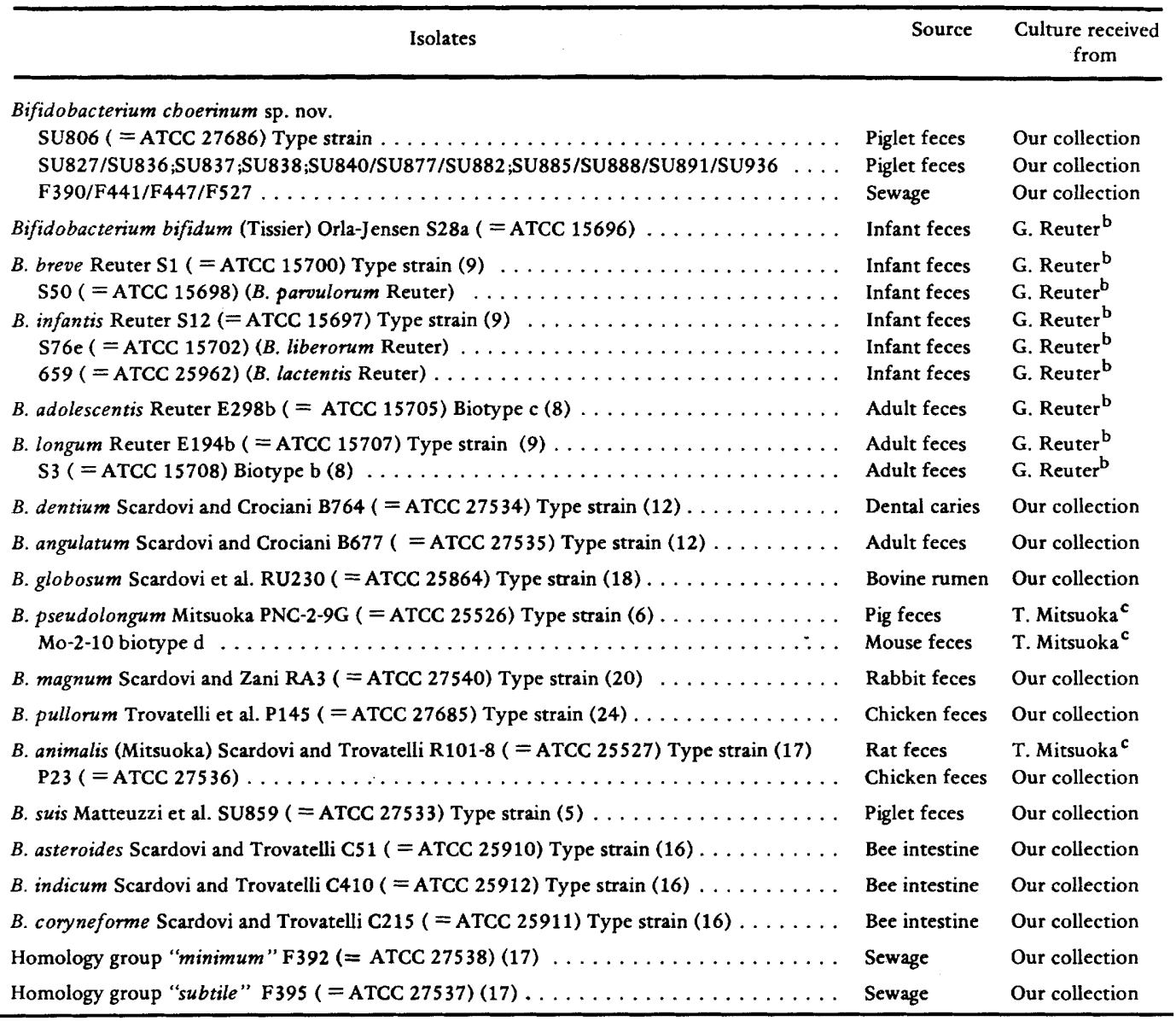

al. [26]), a novel group of bifidobacteria, herein referred to as the boum DNA homology group, emerged; it is also described in this study as a new species.

In 1971 Scardovi et al. (19) described homology group catenulatum on the basis of 10 strains from human feces and vagina and from sewage. Subsequently, an additional 64 isolates from sewage were added to this group, which was proposed as a new species, Bifidobacterium catenulatum (12). Because of the uncertainties in defining the DNA homology values that are valid for separating bacterial species (see ref. 1 , 3 , and 23) and because the known species of the genus Bifidobacterium display interspecific DNA homologies much lower than 40 to $50 \%$, with the exception of $B$. pseudolongum and $B$. globosum, which are 60 to $70 \%$ related (21), many strains from sewage have been included in the species $B$. catenulatum even though they are only 65 to $70 \%$ related to the type strain, B669 (ref. 12, Table 8, p. 12). Two sets of experimental results indicate that the inclusion of these strains is probably incorrect. First, as described here, the new rumen homology group is separated from $B$. thermophilum Mitsuoka ( $B$. ruminale) on the basis of their intergroup DNA relatedness range ( 60 to $80 \%$ ) as determined by a large number of filter-competition tests made with many reference strains from each group. The distinct nature of the peptidoglycan structure and isozyme patterns of these two groups suggests that the DNA homology values do indeed represent distinct entities. Similarly, DNADNA hybridization of a large number of isolates from feces of breast-fed infants (more than 1,500 strains) enabled us to recognize the existence of a large group of isolates which, although similar in many respects to $B$. catenulatum, were only 60 to $80 \%$ related to $B 669$, the type strain of this species. These strains were also phenotypically distinctive. Identical strains were isolated from the feces of suckling calves. The assignment of all sewage strains to the species $B$. catenulatum therefore has to be reconsidered. The closely related strains from humans and calves are here 
TABLE 2. DNA relatedness of $B$. cuniculi and B. choerinum to other species of Bifidobacterium found in animal feces

\begin{tabular}{|c|c|c|c|c|c|c|}
\hline \multirow[b]{2}{*}{ Competitor isolates } & \multicolumn{5}{|c|}{ Percent homology to reference DNA from } & \multirow[b]{2}{*}{$\begin{array}{l}\text { B. animalis } \\
\text { P23 }\end{array}$} \\
\hline & $\begin{array}{l}\text { B. cuniculi } \\
\text { RA93 }\end{array}$ & $\begin{array}{l}\text { B. choerinum } \\
\text { SU806 }\end{array}$ & $\begin{array}{l}\text { B. globosum } \\
\text { RU230 }\end{array}$ & $\begin{array}{l}\text { B. tbermophilum } \\
\text { RU326 }\end{array}$ & $\begin{array}{l}\text { B.pseudolongum } \\
\text { Mo-2-10 }\end{array}$ & \\
\hline \multicolumn{7}{|l|}{ Bifidobacterium cuniculi sp. nov. } \\
\hline RA93 (= ATCC 27916) Type strain & 100 & 15 & 51 & 20 & 16 & 25 \\
\hline RA94;RA95/“;RA98;RA99/ & $97-102-95-101$ & $12-10-9-14$ & $55-60-50-60$ & $15-18-12-16$ & $11-12-8-9$ & $22-24-20-18$ \\
\hline RA104;RA105 & $106-94$ & $10-10$ & $67-52$ & $20-20$ & $10-8$ & $20-18$ \\
\hline Range & $94-102$ & $9-15$ & $50-67$ & $12-20$ & $8-16$ & $18-25$ \\
\hline \multicolumn{7}{|l|}{ Bifidobacterium choerinum sp. nov. } \\
\hline SU806 ( = ATCC 27686) Type strain & 15 & 100 & 48 & 28 & 38 & 18 \\
\hline SU827/SU836;SU837;SU838 & $10-10-8-10$ & $89-75-75-91$ & $26-44-30-43$ & $34-15-33-29$ & $60-40-42-46$ & $4-5-12-17$ \\
\hline SU840/SU877/SU882;SU885/ & $16-8-9-20$ & $92-80-104-86$ & $57-28-39-36$ & $35-16-24-26$ & $57-48-62-48$ & $20-7-9-13$ \\
\hline SU888/SU891/SU936 & $9-8-12$ & $76-90-82$ & $26-42-30$ & $34-30-30$ & $49-49-37$ & $10-21-11$ \\
\hline strains from sewage: F390/F441/F447/F527 & -b_*_** & $116-113-109-120$ & $* * * * * *$ & $* *_{-*}^{*}$ & $*-\cdots+\cdots$ & $* \ldots+\cdots+$ \\
\hline Range & $8-20$ & $75-120$ & $26-57$ & $15-35$ & $37-62$ & 4-20 \\
\hline
\end{tabular}

a Shills (/) separate different specimens from which isolates were obtained.

$b *$, Not tested.

TABLE 3. DNA homology relationships between the species of the genus Bifidobacterium (used as competitors) and the type strains of the new species (used as references)

\begin{tabular}{|c|c|c|c|c|}
\hline \multirow{2}{*}{ Competitor strains } & \multicolumn{4}{|c|}{ Percent homology to reference DNA from } \\
\hline & $\begin{array}{l}\text { B. choerinum } \\
\text { SU806 }\end{array}$ & $\begin{array}{l}\text { B. cuniculi } \\
\text { RA93 }^{2}\end{array}$ & $\begin{array}{l}\text { B. boum } \\
\text { RU917 }\end{array}$ & $\begin{array}{l}\text { B. pseudocatenulatum } \\
\text { B1279 }\end{array}$ \\
\hline Bifidobacterium bifidum $\mathbf{S 2 8 a}$ & 27 & 10 & 11 & 15 \\
\hline B. breve $\mathrm{S} 1 ; \mathbf{S} 50$ & $22-20$ & $13-10$ & $18 * \mathrm{~b}$ & $10-*$ \\
\hline$B$, infantis $\mathrm{S} 12 ; \mathrm{S} 76 \mathrm{e} ; 659$ & $20-21-22$ & $22-16-23$ & $111^{*-*}$ & $15-* *$ \\
\hline B. adolescentis E298 b & 20 & 25 & 25 & 30 \\
\hline B. longum $\mathrm{E} 194 \mathrm{~b} ; \mathrm{S} 3$ & $17-16$ & $16-19$ & $23-*$ & $222^{*}$ \\
\hline B. catenulatum B669 & 32 & 10 & 8 & 58 \\
\hline B. dentium B764 & 15 & 17 & 0 & 18 \\
\hline B. angulatum $\mathrm{B} 677$ & 16 & 17 & 10 & 20 \\
\hline B. globosum RU230 & 50 & 45 & 14 & 5 \\
\hline B. pseudolongum PNC-2-9G; Mo-2-10 & $45-50$ & $10-15$ & $10-*$ & 5-* \\
\hline B. thermophilum P2-91; P16-6; 14-44 & $16-18-15$ & $15-15-20$ & $70-75-72$ & $*_{-}^{*} *_{-}$ \\
\hline Nissin; RU326 (B. ruminale) & 20-19 & $25-17$ & $*-63$ & $*-16$ \\
\hline B. magnum RA3 & 10 & 10 & 12 & 20 \\
\hline B. animalis $\mathrm{R} 101-8 ; \mathrm{P} 23$ & $18-20$ & $31-26$ & $*-21$ & $*-10$ \\
\hline B. pullorum P145 & 37 & 25 & 13 & 12 \\
\hline B. suis SU859 & 21 & 21 & 7 & 25 \\
\hline B. asteroides C51 & 50 & 11 & 0 & 5 \\
\hline B. indicum $\mathrm{C} 410$ & 44 & 20 & - & - \\
\hline B. coryneforme $\mathrm{C} 215$ & 36 & 20 & - & - \\
\hline Homology group "minimum" F392 & 36 & 23 & 0 & 25 \\
\hline Homology group "subtile" F395 & 34 & 14 & 0 & 10 \\
\hline B. choerinum SU806 & 100 & 16 & 20 & 25 \\
\hline B. cuniculi RA93 & 16 & 100 & 5 & 10 \\
\hline B. boum RU917 & 23 & 8 & 100 & 5 \\
\hline B. pseudocatenulatum B1279 & 32 & 10 & 5 & 100 \\
\hline
\end{tabular}

\footnotetext{
a Type strains.
}

$b *$, Not tested. 
regarded as members of a DNA homology group which we refer to as the pseudocatenulatum group; the strains of this group are also described below as belonging to a new species.

(A summary of this paper was presented at the Meeting of the Subcommittee on the Taxonomy of Lactobacilli and Bifidobacteria, Amsterdam, 20-23 April 1975.)

\section{MATERIALS AND METHODS}

Bacterial strains. The strains included in this study are listed in Table 1.
Determination of phenotypic characters. The methods used to determine the phenotypic characters of the strains studied were previously described (12).

DNA-DNA hybridization. The procedure used for determining DNA relatedness was also performed as previously described (12).

Isozyme patterns. The procedures for starch gel electrophoresis and for staining for transaldolase and 6-phosphogluconate dehydrogenase (6PGD) have been described elsewhere (13). The distribution of the multiple electrophoretic forms of these two enzymes among the known species of Bifidobacterium and the numerical identification of these isozymes are reported by Scardovi et al. (11).

TABLE 4. DNA homology relationships between B. boum and B. thermophilum (B. ruminale) determined with five reference strains from each species

\begin{tabular}{|c|c|c|c|c|c|c|c|c|c|c|}
\hline \multirow{3}{*}{$\begin{array}{l}\text { Competitor } \\
\text { isolates }\end{array}$} & \multicolumn{10}{|c|}{ Percent homology to reference DNA from } \\
\hline & \multicolumn{5}{|c|}{ B. boum } & \multicolumn{5}{|c|}{ B. thermophilum } \\
\hline & RU917 & RU318 & RU608 & RU627 & RU929 & RU326 & RU363 & RU408 & RU647 & RU725 \\
\hline \multicolumn{11}{|l|}{ B. boum sp. nov. } \\
\hline RU917 Type strains & 100 & 90 & 95 & 88 & 86 & 60 & 56 & 60 & 58 & 68 \\
\hline RU318 & 102 & 100 & 87 & 84 & 76 & 58 & 52 & 62 & 53 & 72 \\
\hline RU608 & 81 & 84 & 100 & 93 & 85 & 72 & 58 & 70 & 57 & 76 \\
\hline RU627 & 85 & 89 & 95 & 100 & 77 & 52 & 56 & 70 & 62 & 73 \\
\hline RU929 & 92 & 92 & 86 & 90 & 100 & 60 & 49 & 53 & 66 & 70 \\
\hline Range & & & $76-102$ & & & & & $49-76$ & & \\
\hline \multicolumn{11}{|l|}{ B. thermophilum } \\
\hline RU326 (B. ruminale) & 62 & 60 & 64 & 65 & 50 & 100 & 90 & 94 & 98 & 90 \\
\hline RU363 & 65 & 71 & 65 & 72 & 60 & 102 & 100 & 95 & 91 & 96 \\
\hline RU408 & 72 & 41 & 68 & 68 & 60 & 89 & 85 & 100 & 92 & 93 \\
\hline RU647 & 75 & 72 & 77 & 75 & 43 & 103 & 87 & 90 & 100 & 110 \\
\hline RU725 & 76 & 55 & 64 & 63 & 41 & 107 & 83 & 89 & 95 & 100 \\
\hline Range & & & $41-77$ & & & & & $83-110$ & & \\
\hline \multicolumn{11}{|l|}{ Other competitors: } \\
\hline \multicolumn{11}{|l|}{ B. boum } \\
\hline RU312 & 96 & 88 & 90 & 94 & n.t. ${ }^{2}$ & 56 & 68 & 57 & 55 & 74 \\
\hline RU331 & 89 & 87 & 90 & 94 & n.t. & 62 & 68 & 63 & 69 & 71 \\
\hline RU473 & 91 & 96 & 89 & 106 & n.t. & 52 & 73 & 68 & 66 & 72 \\
\hline RU518 & 88 & 91 & 93 & 96 & n.t. & 52 & 67 & 57 & 70 & 71 \\
\hline RU617 & 102 & 88 & 91 & 95 & n.t. & 67 & 69 & 62 & 62 & 75 \\
\hline Range & & & $88-106$ & & & & & $52-75$ & & \\
\hline \multicolumn{11}{|l|}{ B. thermopbilum } \\
\hline RU368 & 50 & n.t. & 77 & 80 & n.t. & 99 & 88 & 95 & n.t. & 98 \\
\hline RU433 & 45 & n.t. & 65 & 71 & n.t. & 83 & 92 & 95 & 93 & 95 \\
\hline RU629 & 67 & n.t. & 75 & 73 & n.t. & 100 & 99 & 90 & 99 & 106 \\
\hline RU673 & 61 & n.t. & 66 & 70 & n.t. & 108 & 93 & 84 & 101 & 102 \\
\hline RU699 & 71 & 59 & 62 & 72 & n.t. & 106 & 100 & 88 & 91 & 96 \\
\hline RU766 & n.t. & 77 & 70 & 69 & n.t. & n.t. & 93 & 91 & n.t. & 103 \\
\hline RU780 & n.t. & 77 & 70 & 82 & n.t. & n.t. & 100 & 92 & n.t. & 108 \\
\hline RU782 & n.t. & 77 & 77 & 77 & n.t. & n.t. & 100 & 86 & n.t. & 105 \\
\hline RU788 & n.t. & 67 & 69 & 67 & n.t. & n.t. & 98 & 89 & n.t. & 110 \\
\hline RU790 & n.t. & 63 & 67 & 75 & n.t. & n.t. & 92 & 90 & n.t. & 109 \\
\hline RU792 & n.t. & 69 & 66 & 69 & n.t. & n.t. & 100 & 97 & n.t. & 107 \\
\hline Range & & & $45-82$ & & & & & $83-110$ & & \\
\hline
\end{tabular}

${ }^{a}$ n.t., Not tested. 


\section{RESULTS}

DNA homology relationships. (i) cuniculi DNA homology group. The data in Table 2 show the strong DNA homogeneity of this group of strains compared with reference strain RA93 (=ATCC 27916). Except for B. globosum RU230 (50 to $67 \%$ homologies), there is little DNA homology with the other strains used in the competition experiments. The cuniculi strains showed little ( 8 to $16 \%$ ) homology with the type strain, Mo-2-10, of B. pseudolongum. These results are further evidence that, as suggested previously (19), B. globosum Scardovi et al. (18) is a taxon distinct from B. pseudolongum Mitsuoka (6), even though $B$. globosum is cited as a synonym of $B$. pseudolongum in the last edition of Bergey's Manual (10). The homology values presented in Table 3 demonstrate that the cuniculi group is genetically distinct from 23 described species and subspecies of Bifidobacterium.

(ii) choerinum DNA homology group. The data in Tables 2 and 3 show the degree of DNA homogeneity of the strains assigned to the choerinum group and that the DNAs from most other species or groups of Bifidobacterium did not significantly compete in the homologous system with strain SU806 as the reference. It is evident, however, that this group is more closely related to $B$. globosum and B. pseudolongum than to any other species of Bifidobacterium. The nearly $50 \%$ homologies with $B$. asteroides and $B$. indicum were unexpected, indeed; such relatedness between bifidobacteria that are so different in morphology, habitat, and other characteristics merits further investigation in relation to its possible significance in the evolution of Bifidobacterium species.

(iii) boum DNA homology group. Because of the rather close DNA relatedness of the boum DNA homology group to $B$. thermophilum ( $B$. ruminale), special attention was given to the assessment of their DNA homology relationships. The data in Tables 4 and 5 show the DNA homology relationships between the strains of this group and $B$. thermophilum. Five reference DNAs and competitor DNAs from additional strains of both groups were used in the reciprocal annealing tests. No overlapping occurred between the ranges of the reciprocal homologies of the two reference groups and those obtained with selected competitors (Table 4). It appears, however, that not all of the reference DNA preparations were suitable for clear-cut discrimination between the two groups of strains. $B$. thermophilum RU725, for example, uniformly showed higher relatedness than did the other reference strains when boum group DNAs were used as competitors (68 to $76 \%$ ); conversely, reference strain RU929 of the boum group gave somewhat lower values when the relatedness of other boum DNAs was measured. It follows that if one used only these two references to separate the two groups of strains, the separation would not be very clear. The homology values obtained with reference strains RU326 (B. thermophilum) and RU917 (boum group) and competitor DNAs from many strains of both groups isolated from rumen, sewage, and feces of piglets are given in Table 5. Although some strains (RU447, RU590, RU663, and RU664) assigned to the boum group displayed a relatedness of only 69 to $76 \%$ to the boum reference strain RU917, their homology to the reference strain RU326 of $B$. thermophilum was much lower. As shown in Table 3, except for B. thermophilum, there was little or no DNA homology between the boum strains and any of the other strains tested.

(iv) pseudocatenulatum DNA homology group. The DNA relatedness of 239 isolates to $\mathrm{B} 1279$, the reference strain of the pseudocatenulatum group, and B669, the type strain of $B$. catenulatum, is reported in Table 6 . The studies generally included multiple isolates from each specimen because the data are part of our investigation of the ecological distribution of Bifidobacterium species and biotypes (unpublished). In Table 6, several strains isolated from the feces of infants, e.g., B1280 to B1561, displayed a relatedness greater than $80 \%$ to $B$. catenulatum reference DNA; nevertheless, these strains were assigned to the pseudocatenulatum group because their homologies to this reference were 20 to $25 \%$ higher. We included strains B2247 to B2266 in the pseudocatenulatum group although their DNA competed poorly in the two reference systems used. These strains were isolated from two fecal specimens from breast-fed infants. The morphology of these strains was unusual (see Fig. 5, no. 7 and 11); however, these strains all fermented starch, as do other pseudocatenulatum strains, and they displayed the same transaldolase and 6PGD isozymes (isozyme 4 and isozyme 3, respectively; see Table 9). When reference DNA was prepared from strains B2247, B2249, and B2262, competition tests (results not tabulated) revealed strong intragroup homology (from 90 to $100 \%$ ) with the isolates from the same specimens. However, the use of DNA competitors from B669, the type strain of B. catenulatum, and B1279 of the pseudocatenulatum group did not permit the assignment of these three strains to either group because the two DNAs competed to the same extent: $80 \%$ to filters B2247 and B2262 and 75\% to filter B2249. The existence of strains intermediate between 
TABLE 5. DNA homology relationships between B. boum and B. thermophilum

\begin{tabular}{|c|c|c|}
\hline \multirow[b]{2}{*}{ Competitor isolates } & \multicolumn{2}{|c|}{ Percent homology to reference DNA from } \\
\hline & $\begin{array}{l}\text { B. boum } \\
\text { RU917 }\end{array}$ & $\begin{array}{l}\text { B. thermophilum } \\
\text { RU326 }\end{array}$ \\
\hline Strains from numen & B. boum sp. nov. & \\
\hline RU917 Type strain & 100 & 63 \\
\hline RU246/2RU276;RU277/RU289/RU313/RU315/ & $83-78-79-79-85-96$ & $67-71-67-67-53-55$ \\
\hline RU334/RU339;RU341/RU346;RU347/RU358/ & $75-95-83-91-81-81$ & $56-64-59-69-59-62$ \\
\hline RU395/RU397/RU400;RU403/RU447/RU590/ & $87-84-76-81-76-75$ & $47-55-57-59-46-59$ \\
\hline RU616/RU663;RU664;RU665/RU683/RU888/ & $93-69-72-81-88-80$ & $70-42-36-64-65-69$ \\
\hline RU928/RU930/ & $95-91$ & $67-74$ \\
\hline \multicolumn{3}{|l|}{ Strains from feces of piglets } \\
\hline SU910;SU911;SU912/SU865/SU873/ & $91-88-92-80-96$ & $63-50-45-36-59$ \\
\hline Range & $69-96$ & $36-74$ \\
\hline \multicolumn{3}{|l|}{ B. thermophilum } \\
\hline \multicolumn{3}{|l|}{ Strains from rumen } \\
\hline RU326 (B. ruminale) & 63 & 100 \\
\hline RU301/RU303;RU306/RU325/RU333/RU349 & $52-53-49-57-66-59$ & $89-85-86-106-100-93$ \\
\hline RU350;RU351/RU364;RU365/RU366;RU367/ & $48-56-48-54-47-50$ & $88-94-110-102-95-85$ \\
\hline RU398/RU402/RU409/RU417;RU419/RU424/ & $41-45-62-56-55-54$ & $83-84-91-92-99-88$ \\
\hline RU426/RU430/RU439/RU458/RU466/RU470/ & $48-55-42-45-47-40$ & $79-100-106-86-85-97$ \\
\hline RU471/RU502/RU516/RU562/RU564;RU568 & $59-80-73-67-57-62$ & $101-100-106-95-83-101$ \\
\hline RU569/RU571/RU648/RU671;RU675/RU718 & $53-65-71-55-67-46$ & $83-110-106-103-117-93$ \\
\hline RU733/RU891;RU892;RU893/RU894;RU895/ & $63-32-71-57-62-52$ & $97-92-92-92-92-84$ \\
\hline RU897;RU899/ & $27-56$ & $97-97$ \\
\hline Range & $27-80$ & $79-117$ \\
\hline \multicolumn{3}{|l|}{ Strains from sewage } \\
\hline F50/F146/F150/F333;F334/F386/ & $40-42-37-42-48-35$ & $80-82-87-90-74-82$ \\
\hline $\mathrm{F} 438 ; \mathrm{F} 440 ; \mathrm{F} 442 ; \mathrm{F} 443 ; \mathrm{F} 445 / \mathrm{F} 451$ & $40-48-42-43-39-30$ & $83-94-90-102-84-85$ \\
\hline $\mathrm{F} 452 / \mathrm{F} 454 ; \mathrm{F} 456 / \mathrm{F} 460 ; \mathrm{F} 466 / \mathrm{F} 489 /$ & $44-35-15-36-40-26$ & $90-82-83-96-96-90$ \\
\hline F491;F493;F494;F499/F523;F524 & $51-34-34-34-30-51$ & $85-86-88-79-88-70$ \\
\hline \multirow[t]{2}{*}{ F534;F536/F539/ } & $35-34-23$ & 83-91-84 \\
\hline & $23-51$ & 74-102 \\
\hline
\end{tabular}

${ }^{a}$ Shills (/) separate different specimens from which isolates were obtained.

the pseudocatenulatum group and B. catenulatum, which cannot be distinguished by reciprocal homology tests with the references used in this study, might be expected because of the close relatedness of the two. However, the nature of these intermediate strains should be investigated further. Three strains-VT74, VT75, and VT77-isolated from the same specimen of calf feces also behaved differently (see Table 6). Their DNA competed to the same low extent in both reference systems (even when $300 \mu \mathrm{g}$ of competitor DNA was used per test); however, unlike the cases described above, the use of strain VT74 as a reference established a clearcut difference between the $B$. catenulatum and pseudocatenulatum DNA competitors used (Table 7). Their phenotypic characters confirm this separation. The data reported in Table 3 show that, except for B. catenulatum, there was little or no homology between the DNA of the pseudocatenulatum strains and any other DNA used in the competition experiments.

Distinctive phenotypic characteristics of the DNA homology groups. (i) Morphology. The general morphology and arrangement of the cells of the DNA homology groups are given in Fig. 1-3, 5, and 6. The morphology of the boum strains (Fig. 3) is comparable to that of strains of B. thermophilum (Fig. 4). Although the morphology of these organisms is not as distinctive 
TABLE 6. DNA homology relationships between B. pseudocatenulatum and B. catenulatum; type strains used as references

\begin{tabular}{|c|c|c|}
\hline Competitor isolates & $\begin{array}{l}\text { Percent homology to } \\
\text { B. pseudocatenulatum } \\
\text { B } 1279\end{array}$ & $\begin{array}{l}\text { NA from } \\
\text { B. catenulatum } \\
\text { B } 669\end{array}$ \\
\hline \multicolumn{3}{|l|}{ B. pseudocatenulatum sp. nov. } \\
\hline \multicolumn{3}{|l|}{ From feces of infant } \\
\hline B1279 (=ATCC 27919) Type strain & 100 & 60 \\
\hline $\mathrm{B} 1280 ; \mathrm{B} 1286 ; \mathrm{B} 1291 ; \mathrm{B} 1297 /^{\mathbf{2}} \mathrm{B} 1330 ; \mathrm{B} 1336$ & $108-100-114-97-109-108$ & $88-79-88-75-59-* b$ \\
\hline $\mathrm{B} 1337 ; \mathrm{B} 1342 / \mathrm{B} 1457 ; \mathrm{B} 1458 ; \mathrm{B} 1460 ; \mathrm{B} 1462$ & $115-101-101-106-101-104$ & $79-*-80-83-79-82$ \\
\hline $\mathrm{B} 1464 ; \mathrm{B} 1466 ; \mathrm{B} 1467 / \mathrm{B} 1555 ; \mathrm{B} 1557 ; \mathrm{B} 1561 /$ & $110-104-100-97-112-110$ & $81-81-76-46-78-78$ \\
\hline $\mathrm{B} 1663 ; \mathrm{B} 1666 ; \mathrm{B} 1669 ; \mathrm{B} 1670 / \mathrm{B} 1735 ; \mathrm{B} 1736 /$ & $96-100-93-98-91-93$ & $70-*-70-*-65-62$ \\
\hline $\mathrm{B} 1828 ; \mathrm{B} 1830 ; \mathrm{B} 1831 ; \mathrm{B} 1832 ; \mathrm{B} 1833 ; \mathrm{B} 1834 /$ & $78-99-90-90-86-90$ & $59-67-73-69-70-68$ \\
\hline $\mathrm{B} 1874 ; \mathrm{B} 1875 ; \mathrm{B} 1879 ; \mathrm{B} 1880 / \mathrm{B} 1886 ; \mathrm{B} 1888 /$ & $89-94-84-92-90-95$ & $62-76-66-* 65-68$ \\
\hline $\mathrm{B} 1889 ; \mathrm{B} 1892 ; \mathrm{B} 1893 / \mathrm{B} 1957 ; \mathrm{B} 1960 ; \mathrm{B} 1961$ & $88-92-95-87-80-85$ & $64-75-70-72-72-74$ \\
\hline B1965;B1966/B1969;B1970;B1973;B1977/ & $104-94-106-100-95-85$ & $74-74-68-63-65-68$ \\
\hline $\mathrm{B} 2067 / \mathrm{B} 2072 ; \mathrm{B} 2073 ; \mathrm{B} 2075 ; \mathrm{B} 2077 ; \mathrm{B} 2078$ & $95-92-91-84-96-80$ & $70-*-58-52-*-69$ \\
\hline $\mathrm{B} 2079 ; \mathrm{B} 2080 ; \mathrm{B} 2082 ; \mathrm{B} 2083 / \mathrm{B} 2247 ; \mathrm{B} 2248$ & $82-80-80-85-\underline{66}-\underline{-61}$ & $69-60-59-72-58-66$ \\
\hline $\mathrm{B} 2249 ; \mathrm{B} 2250 ; \mathrm{B} 2251 ; \mathrm{B} 2252 ; \mathrm{B} 2253 / \mathrm{B} 2262$ & $\underline{68-65}-\underline{-58}-\underline{-65}-\underline{-62-58}$ & $65-64-55-58-58-55$ \\
\hline $\mathrm{B} 2263 ; \mathrm{B} 2266 / \mathrm{B} 2282 ; \mathrm{B} 2283 ; \mathrm{B} 2284 ; \mathrm{B} 2286$ & $\underline{63}-\overline{58}-101-112-98-104$ & $62-56-82-87-74-78$ \\
\hline $\mathrm{B} 2287 ; \mathrm{B} 2288 / \mathrm{B} 2339 ; \mathrm{B} 2340 / \mathrm{B} 2351 ; \mathrm{B} 2359$ & $101-107-106-85-82-93$ & $74-82-68-52-50-58$ \\
\hline $\mathrm{B} 2361 ; \mathrm{B} 2362 ; \mathrm{B} 2363 ; \mathrm{B} 2366 ; \mathrm{B} 2367 / \mathrm{B} 2445 /$ & $99-89-98-94-102-98$ & $46-70-77-74-79-*$ \\
\hline $\mathrm{B} 2446 ; \mathrm{B} 2451 / \mathrm{B} 2540 ; \mathrm{B} 2541 ; \mathrm{B} 2542 ; \mathrm{B} 2543$ & $107-108-104-96-90-85$ & $85-64-611_{-*}^{*}-55$ \\
\hline $\mathrm{B} 2544 ; \mathrm{B} 2545 / \mathrm{B} 2650 ; \mathrm{B} 2651 ; \mathrm{B} 2652 ; \mathrm{B} 2653$ & $110-105-99-89-87-85$ & $75-72-55-52-57-56$ \\
\hline $\mathrm{B} 2654 ; \mathrm{B} 2655 ; \mathrm{B} 2656$ & $100-115-96$ & $63-64-51$ \\
\hline Range & $78-115^{\mathrm{c}}$ & $46-88$ \\
\hline \multicolumn{3}{|l|}{ From sewage (starch positive) } \\
\hline F54/F71/F81/F142/F260 & $114-106-108-95-95-95$ & $82-67-69-70-70-68$ \\
\hline F 262/F331/F356;F360/F434/F469/ & $98-89-109-113-102-85$ & $60-56-68-83-76-65$ \\
\hline $\begin{array}{lll}2 & \text { Range }\end{array}$ & $85-114$ & $60-82$ \\
\hline \multicolumn{3}{|l|}{ From feces of calf } \\
\hline VT6;VT9/VT74;VT75;VT77/VT164 & $90-85-\underline{60}-\underline{58-65}-115$ & $60-62-55-50-60-85$ \\
\hline VT167;VT168;VT169;VT170;VT171;VT172 & $81-90-88-100-88-86$ & $67-60-*-70-65-62$ \\
\hline VT173/VT174;VT179;VT180;VT183/VT185 & $109-90-89-87-89-109$ & $71-69-71-68-68-77$ \\
\hline VT186;VT187/VT201;VT202;VT203;VT204/ & $96-101-88-87-94-105$ & $70-61-58-59-68-71$ \\
\hline VT205;VT206;VT207/VT254/VT262;VT263 & $114-109-104-109-108-90$ & $72-69-73-85-80-75$ \\
\hline VT265;VT269;VT270/VT273;VT274;VT275 & $89-100-96-100-93-81$ & $75-78-80-82-80-69$ \\
\hline VT276;VT277;VT278/VT279;VT282;VT283 & $90-92-92-88-91-94$ & $79-70-79-73-70-73$ \\
\hline VT284;VT285;VT287/VT337;VT339;VT341/ & $93-88-92-84-80-91$ & $79-75-78-50-64-47$ \\
\hline VT348/VT351;VT353;VT354;VT356;VT360/ & $95-85-93-92-79-91$ & $48-64-65-61-47-40$ \\
\hline VT368;VT369;VT370;VT371;VT372;VT373 & $99-96-85-100-115-111$ & $76-65-"-75-81-82$ \\
\hline VT374;VT375/VT393;VT394;VT395/VT396 & $95-102-114-115-100-96$ & $73-79-66-68-75-64$ \\
\hline VT397;VT398;VT399;VT401;VT404/VT405 & $100-101-103-101-89-96$ & $67-69-74-60-69-77$ \\
\hline VT406;VT409 & $85-104$ & $70-64$ \\
\hline Range & $79-115^{c}$ & $40-85$ \\
\hline \multicolumn{3}{|l|}{ B. catenulatum } \\
\hline \multicolumn{3}{|l|}{ From feces of adult man } \\
\hline B669 (=ATCC 27539) Type strain & 58 & 100 \\
\hline $\mathrm{B} 660 / \mathrm{B} 661 / \mathrm{B} 676 / \mathrm{B} 684$ & $52-50-45-52$ & $90-85-102-85$ \\
\hline From buman vagina $\mathrm{B} 933$ & 65 & 95 \\
\hline \multicolumn{3}{|l|}{ From feces of infant } \\
\hline $\mathrm{B} 1331 ; \mathrm{B} 1333 ; \mathrm{B} 1334 ; \mathrm{B} 1338 ; \mathrm{B} 1340 ; \mathrm{B} 1341 /$ & $70-60-67-80-75-71$ & $92-80-88-98-101-100$ \\
\hline $\mathrm{B} 1738 ; \mathrm{B} 1741 ; \mathrm{B} 1742 ; \mathrm{B} 1744 ; \mathrm{B} 1745 ; \mathrm{B} 1746$ & $60-76-62-50-56-59$ & $83-93-96-80-83-85$ \\
\hline $\mathrm{B} 1748 / \mathrm{B} 1955 / \mathrm{B} 2120 ; \mathrm{B} 2121 ; \mathrm{B} 2122 ; \mathrm{B} 2123$ & $59-55-56-56-60-67$ & $84-82-80-85-90-81$ \\
\hline $\mathrm{B} 2124 ; \mathrm{B} 2125 ; \mathrm{B} 2126 ; \mathrm{B} 2127 ; \mathrm{B} 2128 ; \mathrm{B} 2130 /$ & $55-58-60-60-54-62$ & $86-82-92-88-82-90$ \\
\hline $\mathrm{B} 2218 / \mathrm{B} 2238 ; \mathrm{B} 2241 ; \mathrm{B} 2242 ; \mathrm{B} 2243 ; \mathrm{B} 2244$ & $44-63-56-63-60-51$ & $80-80-81-85-82-79$ \\
\hline B2245/B2316/B2415;B2416;B2417;B2418 & $59-60-60-75-74-76$ & $78-81-91-90-98-100$ \\
\hline B2419 & 71 & 95 \\
\hline Range & $44-80$ & $78-101$ \\
\hline \multicolumn{3}{|l|}{ From sewage (starch negative) } \\
\hline F94/F216;F217/F257;F261/F276/ & $60-50-55-50-60-54$ & $86-78-85-80-85-93$ \\
\hline F286/F320;F324/F364/F457/ & $54-59-56-58-70$ & $84-87-82-80-86$ \\
\hline Range & $50-70$ & $80-93$ \\
\hline
\end{tabular}

\footnotetext{
${ }^{a}$ Shills (/) separate different specimens from which isolates were obtained.

$b *$, Not tested.

' Underlined figures were not considered.
} 
TABLE 7. DNA relatedness of some strains from calf feces to $B$. pseudocatenulatum and B. catenulatum

\begin{tabular}{|c|c|c|c|}
\hline \multirow[b]{2}{*}{ Competitor isolates } & \multicolumn{3}{|c|}{ Percent homology to reference DNA from } \\
\hline & $\begin{array}{c}\text { Strain VT74 } \\
\text { (from calf) }\end{array}$ & $\begin{array}{c}\text { B. pseudocatenulatum } \\
\text { B1279 }\end{array}$ & $\begin{array}{l}\text { B. catenulatum } \\
\text { B669 }\end{array}$ \\
\hline \multicolumn{4}{|l|}{ B. pseudocatenulatum } \\
\hline B1279 Type strain & 91 & $100^{2}$ & $60^{2}$ \\
\hline $\mathrm{B} 1280 ; \mathrm{B} 1330 ; \mathrm{B} 1555 ; \mathrm{B} 1663$ & $99-93-94-96$ & $108-109-97-96$ & $88-59-46-70$ \\
\hline $\mathrm{B} 1669 ; \mathrm{B} 1736 ; \mathrm{B} 1830 ; \mathrm{B} 1879$ & $107-106-109-95$ & $93-93-99-84$ & $70-62-67-66$ \\
\hline $\mathrm{B} 1892 ; \mathrm{B} 2073$ & $100-94$ & $92-91$ & $75-58$ \\
\hline Range & $91-109$ & $91-109$ & $58-88$ \\
\hline \multicolumn{4}{|l|}{ B. catenulatum } \\
\hline B669 Type strain & 73 & 58 & 100 \\
\hline B1331;B1340;B1738;B1741 & $50-62-75-64$ & $70-75-60-76$ & $92-101-83-93$ \\
\hline $\mathrm{B} 1748 ; \mathrm{B} 2130$ & $50-74$ & $59-62$ & $84-90$ \\
\hline Range & $50-75$ & $58-76$ & $84-101$ \\
\hline \multicolumn{4}{|l|}{ Strains from feces of calf: } \\
\hline VT74 reference strain & 100 & 60 & 55 \\
\hline VT75;VT77 & $94-105$ & $58-65$ & $50-60$ \\
\hline
\end{tabular}

a The figures of these two columns are taken from Table 6.

as the morphology of others, such as $B$. bifidum, $B$. angulatum, B. breve, B. asteroides, B. pullorum, etc., distinguishing features can be recognized, especially when the cells are grown on solid TPY medium (Trypticase-phytone-yeast extract-glucose medium; BBL Microbiology Systems). These features are included in the detailed descriptions of these organisms (see below).

(ii) Fermentation patterns. The fermentation patterns of the cuniculi, boum, and choer. inum groups are reported in Table 8 . The lack of raffinose fermentation is characteristic of cuniculi strains. This negative characteristic is also common to $B$. bifidum and to the "minimum" homology group (17). The carbohydrates fermented by boum strains are the same as those fermented by $B$. thermophilum (B. ruminale) $(6,18)$. choerinum strains do not possess a fermentation pattern that differentiates them from other organisms. The only difference between the pseudocatenulatum and the B. catenulatum strains was in the fermentation of starch (and dextrin): all of the pseudocatenulatum strains fermented starch, whereas none of the $B$. catenulatum strains did. Strain B669 (=ATCC 27539), the type strain of $B$. catenulatum, has erroneously been reported as fermenting starch (see ref. 12, Table 11, p. 17).

(iii) Amino acid composition of the cell wall peptidoglycan. The interpeptide bridges of the cell wall mureins of the reference strains of the four homology groups are as follows (Kandler, personal communication): cuniculi, Orn(Lys)-Ala(Ser)-Ala ; choerinum, Orn(Lys)-
Ser-Ala 2 ; boum, Lys-Ser-Glu; and pseudocatenulatum, Lys-Ala $a_{2}$-Ser. Kandler and Lauer (4) reported that the structure of the interpeptide bridge in $B$. thermophilum was of the type Orn(Lys)-Glu, which is distinct from that of the boum homology group. The Lys-Ser-Glu type found in the boum group is a type previously unknown among bifidobacteria. According to these authors (4), the cell wall peptidoglycan of the type strain of $B$. catenulatum (strain B669) was of the Lys-Asp type, whereas the interpeptide bridge in pseudocatenulatum strain B1279 is Lys-Ala I $_{2}$ Ser, a type also found in $B$. magnum (20). The differentiation of the boum and pseudocatenulatum groups from $B$. thermophilum and the starch-hydrolysis-negative strains of $B$. catenulatum, respectively, appears to be possible on the basis of their type of cell-wall peptidoglycan.

(iv) $\mathbf{G}+\mathbf{C}$ content of DNA. The guanine plus cytosine $(\mathrm{G}+\mathrm{C})$ contents of the DNAs of the four groups were: cuniculi, $64.1 \pm 0.35 \mathrm{~mol} \%$; choerinum, $66.3 \pm 0.15 \mathrm{~mol} \%$; boum, $60.0 \pm 0.2$ $\mathrm{mol} \%$; and pseudocatenulatum, $57.5 \pm 0.3 \mathrm{~mol} \%$. The value for the choerinum group is high for bifidobacteria, but 66 to $68 \mathrm{~mol} \% \mathrm{G}+\mathrm{C}$ was reported for $B$. pullorum (24). The value for the boum group does not differ from that reported for $B$. thermophilum (10), but the value for the pseudocatenulatum group is significantly higher than the value $(54.7 \pm 0.3 \mathrm{~mol} \%)$ reported for $B$. catenulatum (12).

(v) Isozyme patterns of transaldolase and 6PGD. Recent investigations (11) on more than 1,200 strains representing all the currently 

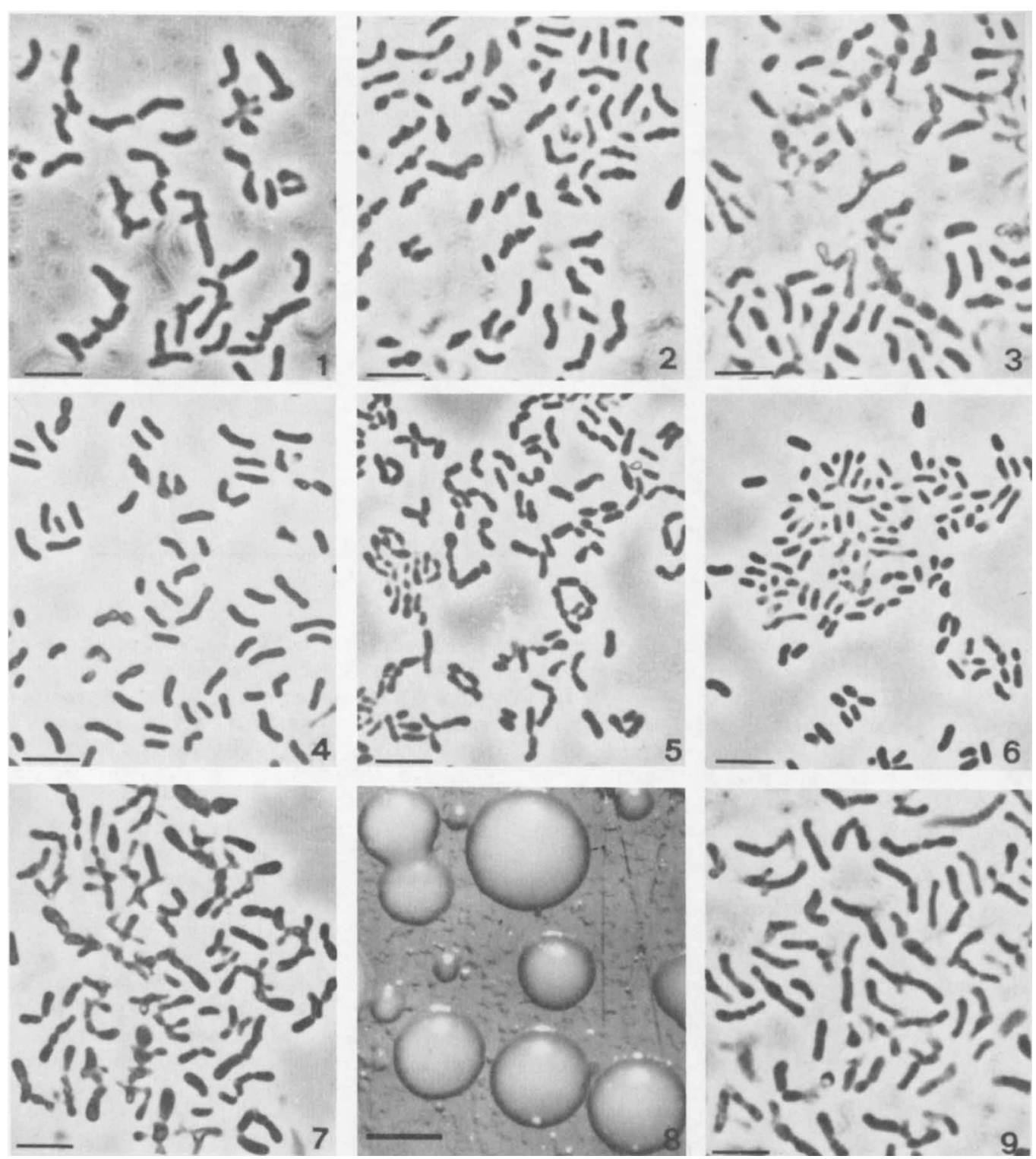

Fig. 1. Morphology of Bifidobacterium cuniculi sp. nov. (1) Cells of the type strain, RA93, from the first anaerobic stab culture (TPY medium) after isolation (July 1972). (2 and 3) Cells of strains RA99 and RA105, respectively, as above. (4) Cells of strain RA93, received as ATCC 27916, from the first transfer in TPY medium (anaerobic stab). (5) Cells of strain RA93 from a surface colony in TPY medium. (6) Cells of the type strain from liquid culture in TPY medium with glucose. (7 and 9) Cells of the type strain from starch and maltose broth cultures, respectively. Phase contrast. Bars, $5 \mu \mathrm{m}$. (8) Two-day-old surface colonies of the type strain, RA93, on TPY medium. Bar, $1 \mathrm{~mm}$.

known species or homology groups of Bifidobacterium, concerning the presence and distribution of isozymes of transaldolase and 6PGD, have shown that at least 14 and 19 forms of these two enzymes, respectively, can be detected by means of starch gel electrophoresis. Most species or groups of bifidobacteria displayed a characteristic set of isozymes by virtue of their widely differing migration rates. The zymogram technique applied to these enzymes therefore constitutes an additional tool for the differentiation of the species of Bifidobacterium. Data summa- 

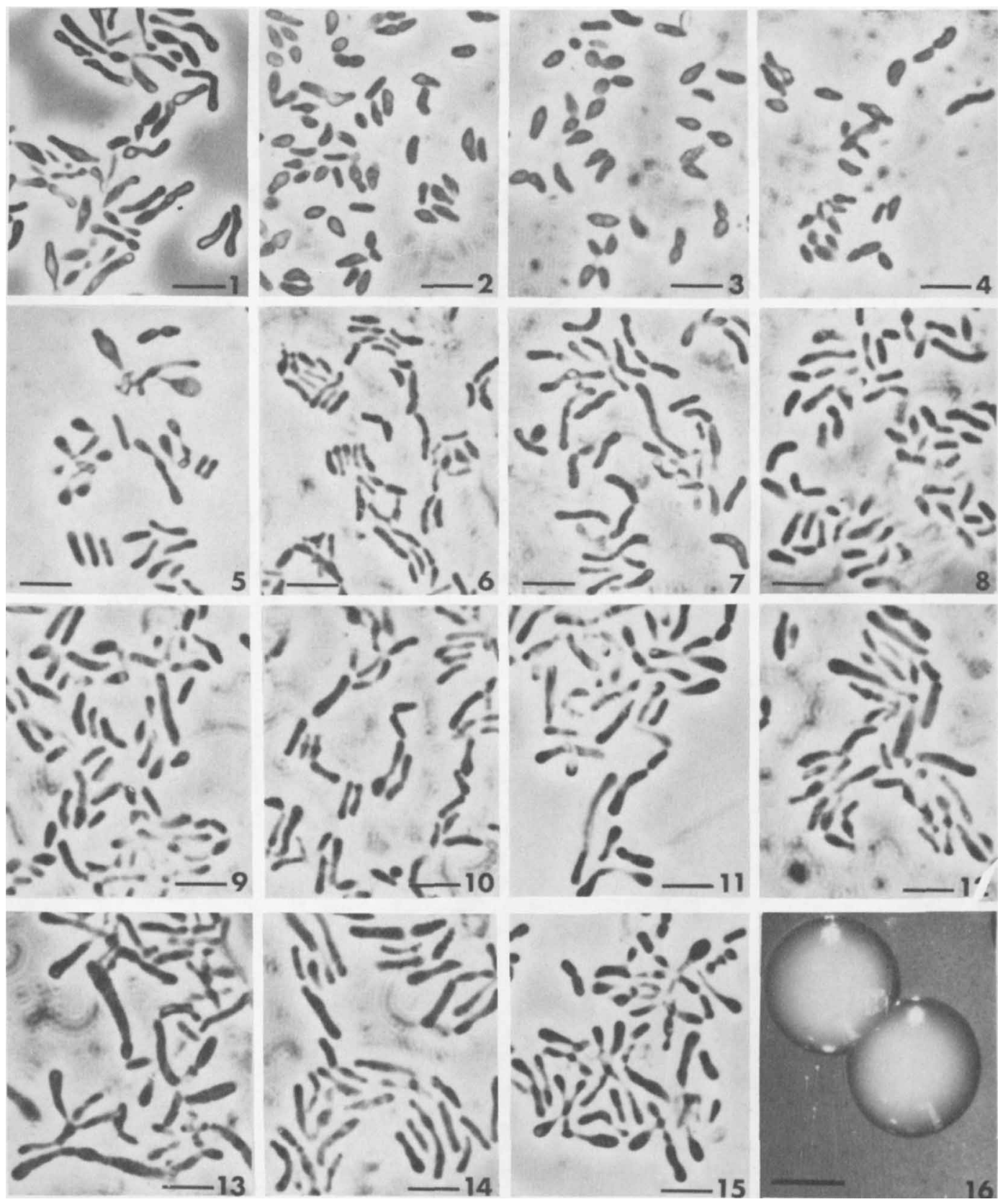

Fig. 2. Morphology of Bifidobacterium choerinum sp. nov. (1) Cells of the type strain, SU806 $(=A T C C$ 27686), from an anaerobic stab culture (TPY medium). (2 to 5) Cells of strains SU840, SU877, SU838, and SU827, respectively, from the first anaerobic stab culture (TPY medium) after isolation (February 1969). (6 and 7) Cells of the type strain from liquid culture (TPY medium). (8 to 10) Cells of strains SU885, SU882, and SU837, respectively, from liquid cultures (DNA extraction). (11) Cells of strain F390 from the first anaerobic stab culture (TPY medium) after isolation (October 1970). (12) Cells of strain F390 from liquid culture (DNA extraction). (13) Cells of strain SU837 from 6-day-old liquid culture (TPY medium with glucose). (14) Cells of strain F447 from liquid culture (DNA extraction). (15) Cells of strain F527 from anaerobic stab culture (TPY medium). Phase contrast. Bars, $5 \mu \mathrm{m}$. (16) Two-day-old colonies of the type strain, SU806 (TPY medium). Bar, $1 \mathrm{~mm}$. 


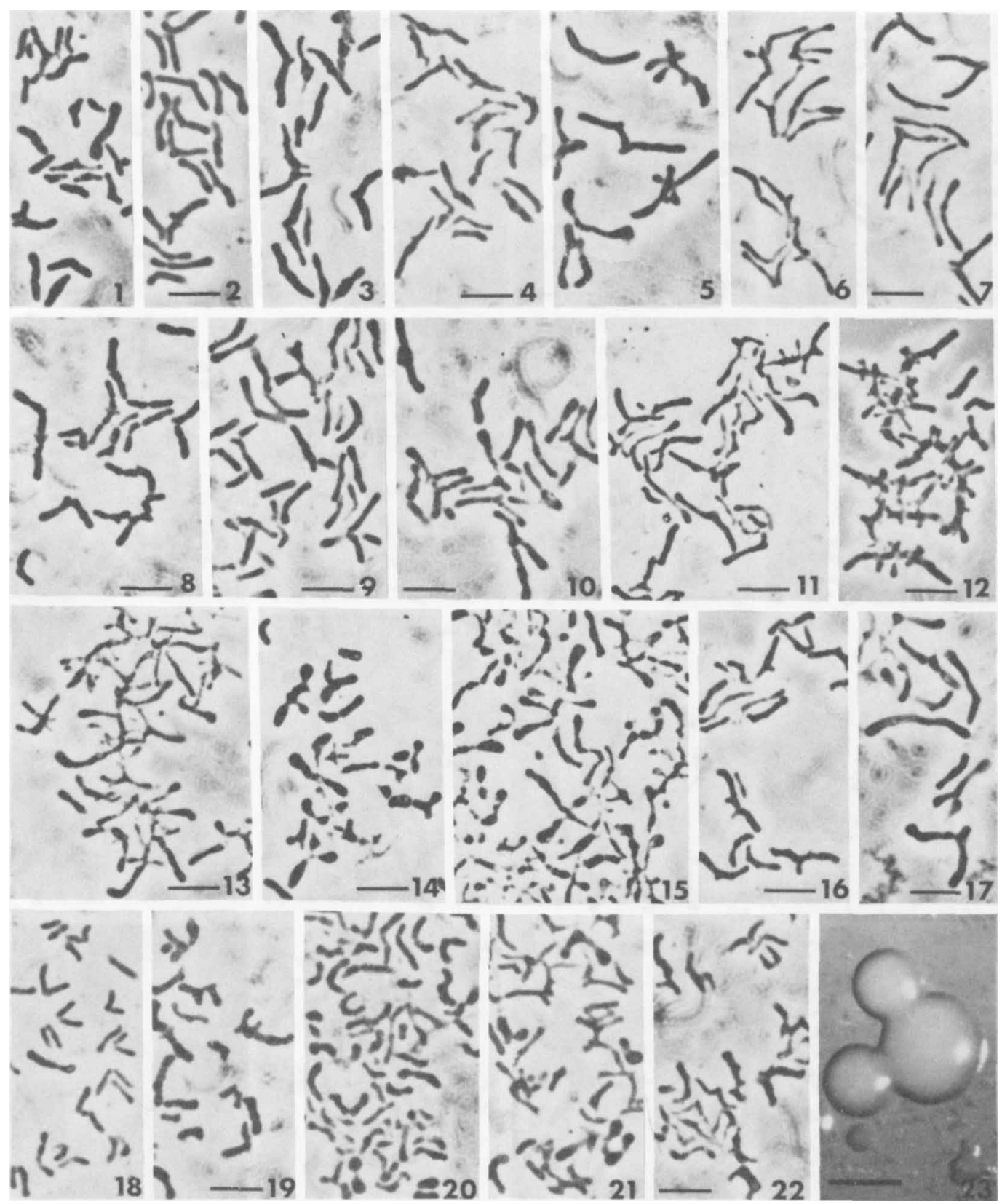

FIG. 3. Morphology of Bifidobacterium boum sp. nov. (1) Cells of the type strain, RU917, from an anaerobic stab culture (TPY medium). (2) Cells of the type strain from surface colonies of TPY medium [see (23)]. (3 to 6) Cells of strains $R U 318, R U 929, R U 608$, and RU279, respectively, from anaerobic stab cultures (TPY medium). (7) Cells of strain RU334 from broth culture (DNA extraction). (8 to 11) Cells of strains RU447, RU312, RU315, and RU358, respectively, from anaerobic stab cultures (TPY medium). (12) Cells of strain RU312 from a slant culture under CO.2-air. (13 to 17) Cells of strains RU289, RU347, RU334, RU627, and $R U 315$, respectively, from anaerobic stab cultures (TPY medium). (18) Cells of strain SU911 from an anaerobic stab culture (TPY medium). (19 to 21) Cells of strains SU910, SU912, and F375, respectively, from broth cultures (DNA extraction). (22) Cells of strain SU873 from an anaerobic stab culture (TPY medium). Phase contrast. Bars, $5 \mu \mathrm{m}$. (23) Two-day-old surface colonies of the type strain, RU917 (=ATCC 27917), on TPY medium. Bar, $1 \mathrm{~mm}$. 


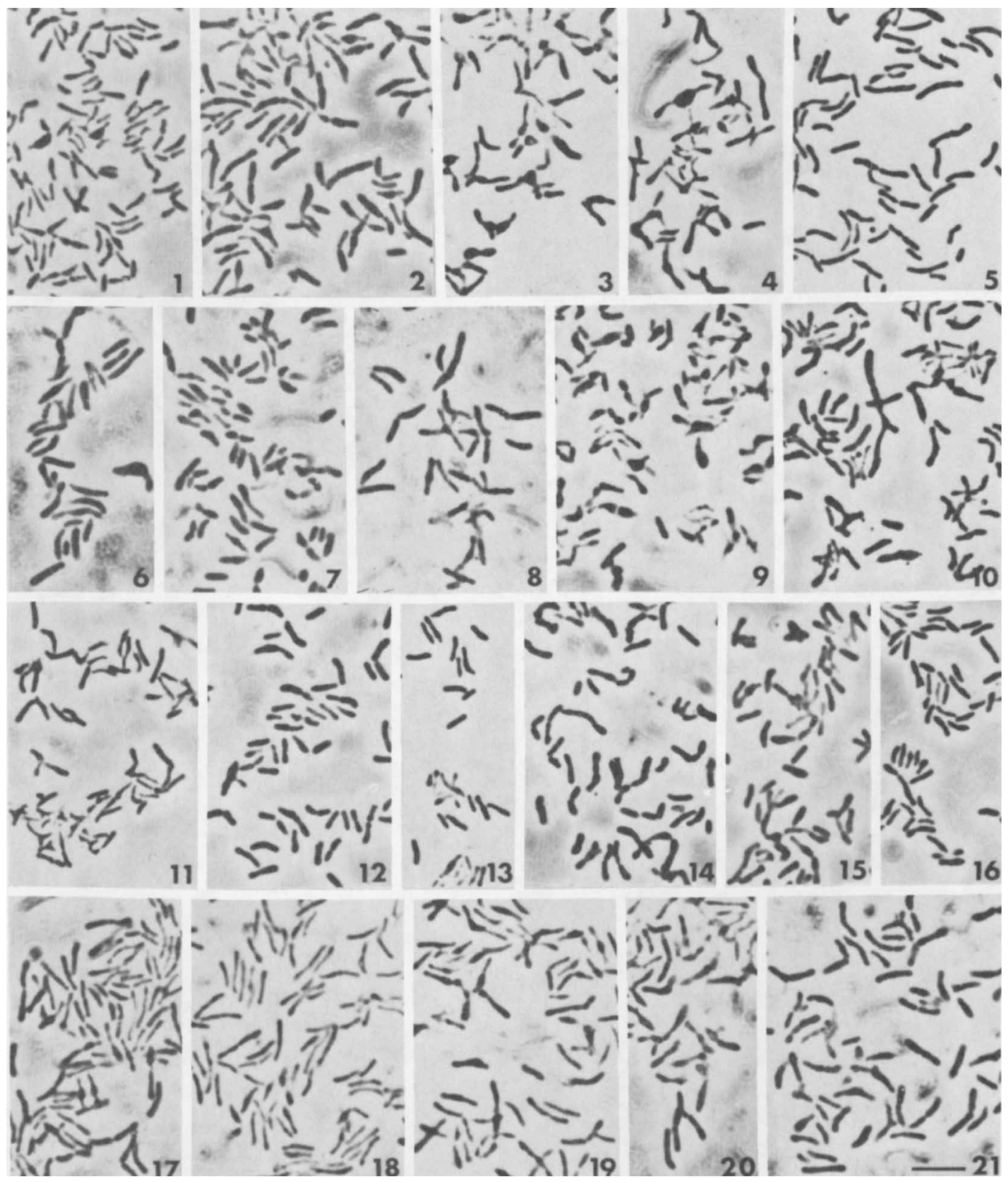

Fig. 4. Morphology of Bifidobacterium thermophilum (B. ruminale). (1 and 2) Cells of strain RU326 (type strain of B. ruminale) from broth cultures (TPY medium). (3 and 4) Cells of strains RU326 and RU363, respectively, from anaerobic stab cultures (TPY medium). (5) Cells of strain P2-91 (type strain of B. thermophilum, =ATCC 25525) from a broth culture (DNA extraction). (6 to 8) Cells of strains RU408, RU647, and $R U 725$, respectively, from broth cultures (DNA extraction). (9 and 10) Cells of strains RU301 and RU349, respectively, from anaerobic stab cultures (TPY medium). (11) Cells of strain RU346 from a slant culture under $\mathrm{CO}_{2}$-air. (12 and 13) Cells of strains $\mathrm{RU} 366$ and $\mathrm{RU} 402$, respectively, from broth culture (TPY medium). (14 and 15) Cells of strains RU430 and RU458, respectively, from anaerobic stab cultures (TPY medium). (16) Cells of strain RU458 from broth culture (TPY medium) (17 to 21) Cells of strains RU471, RU516, RU562, RU788, and RU790, respectively, from anaerobic stab cultures (TPY medium). Phase contrast. Bar, $5 \mu m$. 

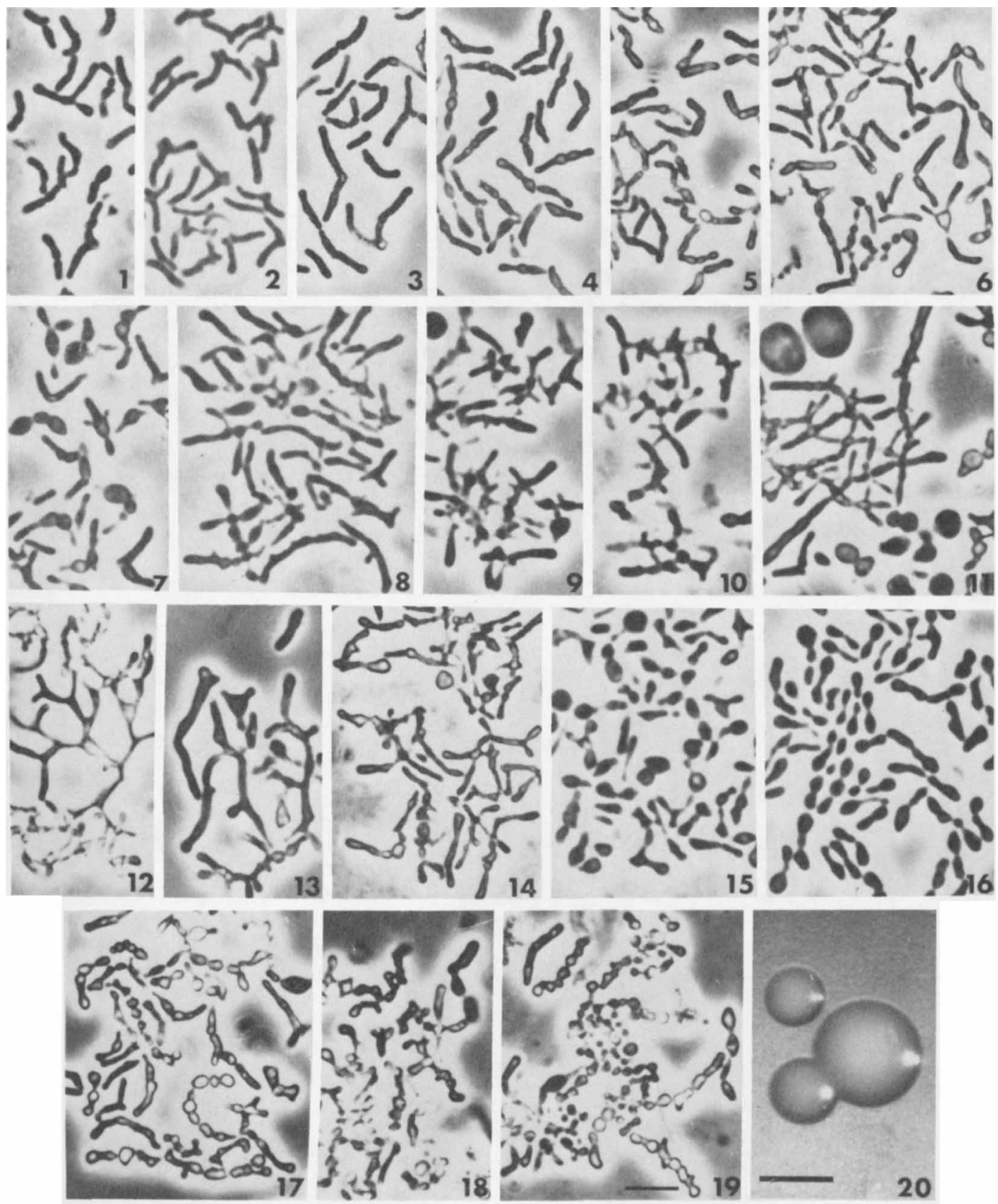

FIG. 5. Morphology of Bifidobacterium pseudocatenulatum sp. nov. Strains isolated from infant feces. (1) Cells of the type strain, B1279, received as ATCC 27919, from the first transfer in TPY medium (anaerobic stab culture). (2) Cells of the type strain from a surface colony on TPY medium [see (20)]. (3 to 6) Cells of strains B1970, B2287, B2351, and B2072, respectively, from anaerobic stab cultures (TPY medium). (7) Cells of strain B2262 from an anaerobic stab culture (TPY medium). (8 to 10) Cells of strains B2282, B2284, and $B 2286$, respectively, from the first anaerobic stab culture (TPY medium) after isolation (December 1974). (11 to 16) Cells of strains B2249, B1666, B2544, B1977, B2653, and B2654, respectively, from anaerobic stab cultures (TPY medium). (17 to 19) Cells of strains B2282, B2284, and B2286, respectively, from anaerobic stab cultures [April 1976, see (8) to (10)]. Phase contrast. Bar, 5 um. (20) Two-day-old colonies of the type strain, B1279 (TPY medium). Bar, $1 \mathrm{~mm}$. 
rized in Table 9 show the isozymes (numbered according to their decreasing migration toward the anode) that have been detected in the strains of the four groups under study. The relative electrophoretic migration of these isozymes is illustrated in Fig. 7. The differences between the isozyme sets of boum strains and pseudocatenulatum strains and those of $B$. thermophilum and $B$. catenulatum, respectively, add phenotypic evidence for the taxonomic separation of these organisms.

Physiological and biochemical characters. With respect to the physiological and biochemical characteristics that were investigated-relationships to oxygen and $\mathrm{CO}_{2}$, tem- perature and $\mathrm{pH}$ relationships, end products from glucose, and biochemical reactions-the four groups do not differ from most other bifidobacteria.

\section{DISCUSSION}

We have used DNA-DNA homology values as the primary basis for differentiating the species of the genus Bifidobacterium. Many authors (see Brenner [1]) accept 70\% DNA homology as the "species" level of relatedness and 60 to $70 \%$ homology as the level of "geno-subspecies" relatedness (3). However, some of the earlier proposed $(6,8)$ species of Bifidobacterium showed

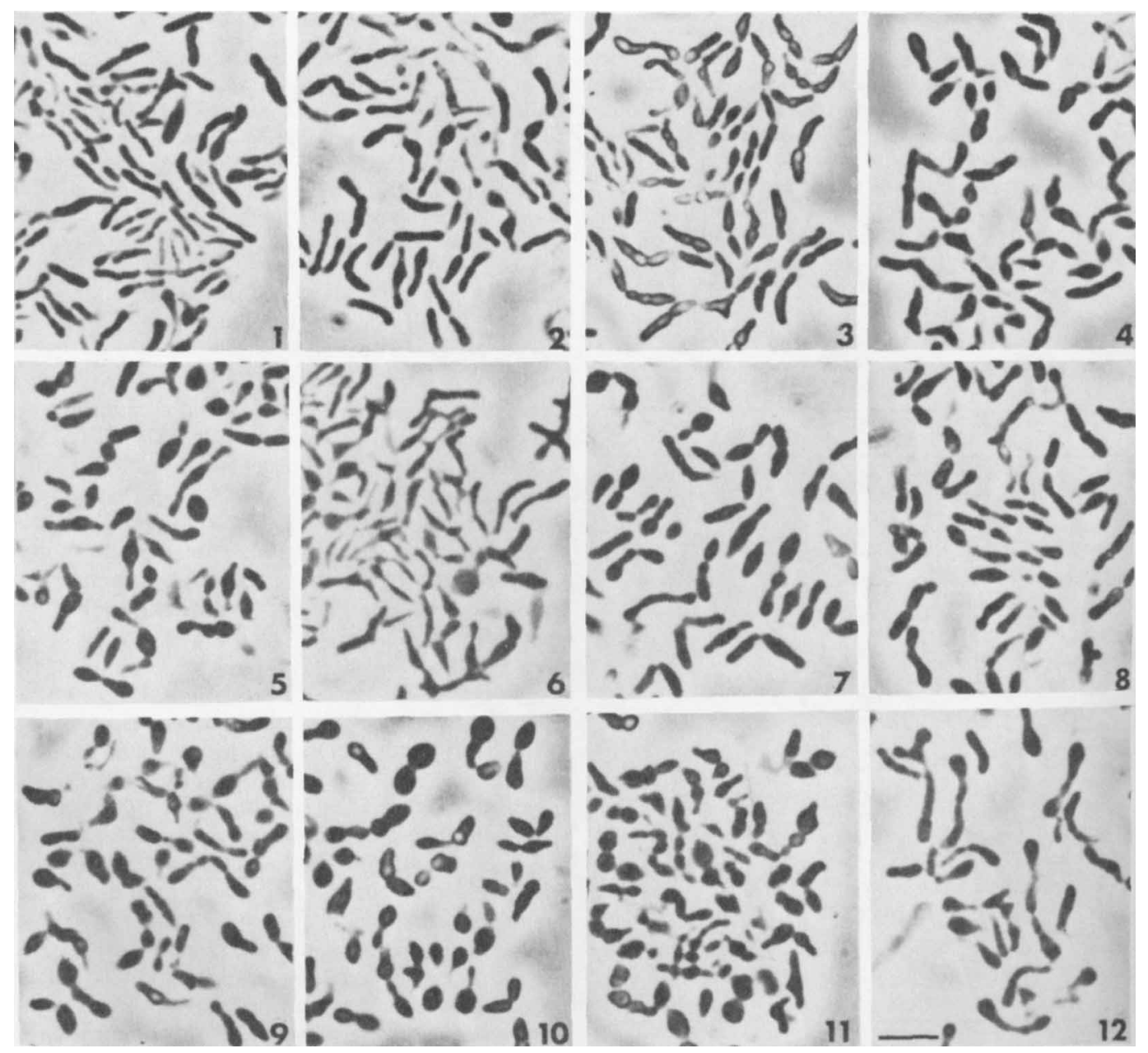

FIG. 6. Morphology of Bifidobacterium pseudocatenulatum sp. nov. Strains isolated from the feces of suckling calves. (1) Cells of strain VT164 from a broth culture (DNA extraction). (2 to 8) Cells of strains VT187, VT399, VT279, VT171, VT282, VT164, and VT183, respectively, from anaerobic stab cultures (TPY medium). (9 to 11) Cells of strains VT356, VT337, and VT270, respectively, from anaerobic stab cultures (TPY medium). (12) Cells of strain VT178 from a broth culture (DNA extraction). Phase contrast. Bar, $5 \mu \mathrm{m}$. 
TABLE 8. Fermentation patterns of B. cuniculi, $B$. boum, and $B$. choerinum ${ }^{a}$

\begin{tabular}{lccc}
\hline \multicolumn{1}{c}{ Compound } & $\begin{array}{c}\text { B. cuniculi } \\
7 \text { strains }\end{array}$ & $\begin{array}{c}\text { B. boum } \\
41 \text { strains }\end{array}$ & $\begin{array}{c}\text { B. cboerinum } \\
16 \text { strains }\end{array}$ \\
\hline Fructose & $-b$ & + & -6 \\
L-Arabinose & + & - & - \\
D-Xylose & + & - & - \\
Lactose & - & + & + \\
Raffinose & - & + & + \\
Inulin & - & + & - \\
\hline
\end{tabular}

${ }^{a}$ All strains fermented glucose, galactose (weak fermentation in some $B$. boum strains), sucrose, maltose, melibiose (see below), starch, and dextrin. Melibiose, fermented by all strains of $B$. boum and $B$. choerinum, was not fermented by the type strain of $B$. cuniculi (ATCC 27916) (W. E. C. Moore, personal communication); however, we repeatedly obtained positive results with this strain. None fermented ribose (weak and occasional fermentation in $B$. choerinum), mannose, trehalose, cellobiose, melezitose, mannitol, sorbitol, gluconate, salicin, glycerol, rhamnose, or lactate.

${ }^{b}$ The behavior toward fructose seems to be influenced by the reducing conditions of the medium: fermentation is positive in prereduced media (W. E. C. Moore, personal communication).

' Ten strains of this species fermented lactose: RU276, RU346, RU397, RU400, RU403, SU865, SU873, SU910, SU911, and SU912.

TABLE 9. Transaldolase and 6PGD isozyme distribution in the four new species and in $B$. thermophilum and B. catenulatum

\begin{tabular}{|c|c|c|c|}
\hline Species and sources & Number of & & ee of \\
\hline $\begin{array}{l}\text { B. cuniculi } \\
\text { from rabbit feces }\end{array}$ & $7^{e}$ & $1^{n}(7)^{b}$ & $4^{t}(7)^{b}$ \\
\hline $\begin{array}{l}\text { B. cboerinum } \\
\text { from piglet feces } \\
\text { from sew2ge }\end{array}$ & $\begin{array}{r}13 \\
2\end{array}$ & $\begin{array}{l}3(13) \\
3(2)\end{array}$ & $\begin{array}{l}4(13) \\
4(2)\end{array}$ \\
\hline $\begin{array}{l}\text { B. boum } \\
\text { from numen }\end{array}$ & 19 & $6(19)$ & $\begin{array}{l}8(10) \\
9(6) \\
9 a(3)\end{array}$ \\
\hline from piglet feces & 3 & $6(3)$ & $9(3)$ \\
\hline $\begin{array}{l}\text { B. thermopbilum } \\
\text { from rumen }\end{array}$ & 39 & $8(39)$ & $\begin{array}{l}7(10) \\
8(12) \\
9(16) \\
92(1)\end{array}$ \\
\hline from sewage & 21 & $8(21)$ & $\begin{array}{l}8(5) \\
9(16)\end{array}$ \\
\hline from pig feces & 9 & $8(9)$ & $\begin{array}{l}8(5) \\
9(4)\end{array}$ \\
\hline $\begin{array}{l}\text { B. pseudocatenulatum } \\
\text { from infant feces }\end{array}$ & 65 & $4(65)$ & $\begin{array}{l}1(40) \\
3(25)\end{array}$ \\
\hline from calf feces & 35 & $\begin{array}{l}4(28) \\
5(7)\end{array}$ & $3(35)$ \\
\hline from sewage & 20 & $4(20)$ & $1(20)$ \\
\hline $\begin{array}{l}\text { B. catenularum } \\
\text { from infant feces }\end{array}$ & 21 & $5(21)$ & $\begin{array}{l}6(15) \\
8(6)\end{array}$ \\
\hline $\begin{array}{l}\text { from aduit feces } \\
\text { from sewage }\end{array}$ & $\begin{array}{r}6 \\
17\end{array}$ & $\begin{array}{l}5(6) \\
5(17)\end{array}$ & $\begin{array}{l}6(6) \\
6(17)\end{array}$ \\
\hline
\end{tabular}

${ }^{a}$ The isozymes are numbered in the order of their decreasing rate of electrophoretic migration toward the anode (11).

${ }^{b}$ Numbers in parentheses are the numbers of strains that were endowed with the corresponding isozyme.

"The labels of the strains studied are reported elsewhere (11).

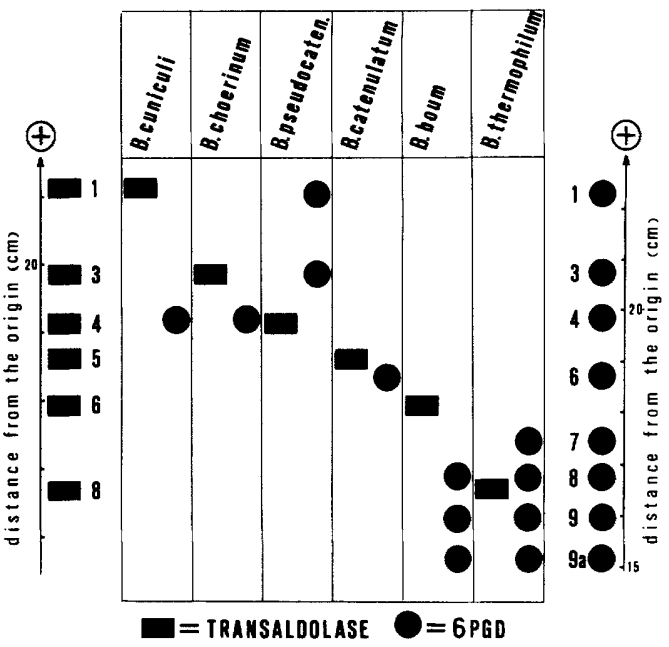

FIG. 7. Diagrammatic representation of the electrophoretic forms of transaldolase and 6PGD in the four new species and in $B$. catenulatum and $B$. thermophilum (B. ruminale). The isozymes are numbered as in ref. 11. The migration distances (in centimeters) of the two sets of isozymes were observed in separate runs. The distribution of these isozymes among the strains studied is reported in Table 9.

less than 30\% DNA relatedness (19). As more strains of bifidobacteria from different sources have been examined, some new groups have emerged that show high ( $70 \%$ or more) intragroup and moderate (40 to $80 \%$ ) intergroup relatedness. In addition, these distinct clusters of strains have some phenotypic characteristics, including $\mathrm{G}+\mathrm{C}$ content of DNA, composition of cell wall peptidoglycan, fermentation of certain carbohydrates, and isozyme pattern of transaldolase and 6PGD, that correlate with their homology patterns. We believe that these entities should be recognized as distinct (but closely related) species.

Detection of such closely related species depends heavily on the choice of reference strains (see Staley and Colwell [23]), but these distinct organisms may well have significance in the evolutionary sense of taxonomy. Further studies, such as ribosomal ribonucleic acid-DNA hybridization, should help in the interpretation of these relationships. Discovery of these phenotypic differences among closely related species is indeed fortunate because some other genetically unrelated species in the genus cannot yet be differentiated phenotypically. For example, $B$. adolescentis is presently phenotypically indistinguishable from $B$. dentium, yet these species show less than $30 \%$ homology (12). Similar examples are known in Pseudomonas (7) and in Fusobacterium and Bacteroides (3).

The opinion has been expressed (Brenner, ref. 1, p. 305) that "a taxonomic scheme is useful if 
it enables a worker to distinguish between organisms." But the ecological significance of genetically distinct entities is probably relevant, and it may not be appreciated until the phenotypic expressions of the DNA differences are discovered. Meanwhile, recognition of distinct entities which can be confused phenotypically has both practical and scientific merit and should be considered whenever research or diagnostic data are interpreted.

Consequently it is here proposed that the four DNA homology groups described above be accorded species rank, as follows.

1. Bifidobacterium cuniculi sp. nov. (cu. ni 'cu. li. L. n. cuniculus rabbit; L. gen. n. cuniculi of the rabbit).

Cell characteristics. Gram-positive, nonmotile, nonsporeforming, stout rods, 2 to $4 \mu \mathrm{m}$ in length, with irregular contours and small central swellings or knobs. Chains of cells, with apparently pedunculate symmetrical sprouts, occur rarely. Extensive branching occurs only in liquid cultures with fermentable sugars like starch or maltose. In Trypticase-phytone-yeast extract-glucose (TPY) liquid medium, the cells are generally shorter and have nearly regular contours. This general morphology is very similar to that of $\boldsymbol{B}$. globosum; however, the short knobs or protuberances, often at the middle of the cells, are characteristic of $B$. cuniculi cells grown in solid TPY medium (see Fig. 1).

Surface colonies (TPY medium). Smooth, convex, cream to white, glistening and soft; entire edges.

Relationships to oxygen and $\mathrm{CO}_{2}$. Highly anaerobic; $\mathrm{CO}_{2}$ has no effect upon oxygen sensitivity and anaerobic growth.

Temperature relationships. Optimum, 36 to $38^{\circ} \mathrm{C}$; minimum, about $29^{\circ} \mathrm{C}$; maximum, 42.5 to $43^{\circ} \mathrm{C}$; no growth occurs at 28.5 or $44^{\circ} \mathrm{C}$.

pH relationships. Initial optimum $\mathrm{pH}$ is 6.7 to 7.1 ; growth is retarded at 6.4 and 7.6 ; no growth occurs at 5.0 or 8.5 .

Fermentation pattern. Glucose, galactose, arabinose, xylose, sucrose, maltose, melibiose, starch, and dextrin are fermented. Fructose is fermented regularly only in prereduced media. Ribose, mannose, trehalose, cellobiose, lactose, melezitose, raffinose, mannitol, sorbitol, inulin, salicin, and gluconate are not fermented. As with other bifidobacteria, glycerol, rhamnose, and lactate are not fermented. Lactose and raffinose are characteristically not fermented by this species.

End products from glucose fermentation. The molar ratio of lactic to acetic acid from the fermentation of glucose varies between strains: from 1:5 (strain RA93) to 1:20 (strain RA98). L(+)-lactic acid is produced. Small amounts of formic acid are produced. Propionic and butyric acids are not produced.

Biochemical reactions. Catalase and pseudocatalase (hemin) are not produced; nitrate is not reduced; indole is not produced; acetylmethylcarbinol is produced; gelatin is not liquefied; skim milk is unchanged; ammonia is not produced from urea or arginine.

$\mathrm{G}+\mathrm{C}$ content of the DNA. The $\mathrm{G}+\mathrm{C}$ content of the DNA is $64.1 \pm 0.35 \mathrm{~mol} \%\left(\mathrm{~T}_{\mathrm{m}}\right)$.

DNA relationships. The DNA of this species showed little or no homology (10 to $30 \%$ ) with that of any other species (or group) of Bifidobacterium except the DNA of the type strain of B. globosum (RU230 = ATCC 25864), with which homologies ranged from 50 to $67 \%$.

Amino acid composition of the cell wall peptidoglycan. The interpeptide bridge of the murein of the cell wall of the type strain is Orn(Lys)-Ala(Ser)-Ala ${ }_{2}$ (O. Kandler, personal communication).

Isozyme pattern. Produces transaldolase isozyme 1 and 6PGD (oxidized nicotinamide adenine dinucleotide phosphate dependent) isozyme 4 ; this 1-4 pattern is unique among the bifidobacteria.

Source. Feces of adult rabbits.

Type strain. The type strain is RA93 from the Collection of the Istituto di Microbiologia Agraria, Università di Bologna, Italy. A culture of this strain has been deposited in the American Type Culture Collection, Rockville, Md., under the number 27916.

2. Bifidobacterium choerinum sp. nov. (choe. ri 'num. M. L. adj. choerinus pertaining to a pig).

Cell characteristics. Gram-positive, nonmotile, nonsporeforming, spindle- or lemonshaped cells, 1.5 to $3.5 \mu \mathrm{m}$ long when freshly isolated. Cells occur singly or in pairs; after subculture in TPY medium, the cells are distinctly longer (6 to $7 \mu \mathrm{m}$ ), with irregular contours; very few cells have branches. Cells are generally more uniform in shape when grown in liquid TPY medium; they are elongated (10 to $12 \mu \mathrm{m})$, slightly bent, and with rounded ends. Some cells with enlarged extremities occur in starlike aggregates (see Fig. 2).

Surface colonies (TPY medium). Smooth, convex, cream to white, glistening, and soft; entire edges.

Relationships to oxygen and $\mathrm{CO}_{2}$. Slightly anaerobic. Effect of $\mathrm{CO}_{2}$ not detectable.

Temperature relationships. Optimum, 41 to $42.5^{\circ} \mathrm{C}$; minimum, about $27^{\circ} \mathrm{C}$; maximum, 44.5 to $45.0^{\circ} \mathrm{C}$; no growth at 25 or $46^{\circ} \mathrm{C}$.

pH relationships. Initial optimum $\mathrm{pH}$ is 6.5 to 7.3 ; growth is retarded at 6.2 or 7.6; no growth at 5.2 or 8.5 (after 2 days).

Fermentation pattern. Ribose, glucose, ga- 
lactose, sucrose, maltose, melibiose, lactose, starch, and dextrin are fermented. Fructose is ordinarily fermented only in prereduced media. Arabinose, xylose, mannose, trehalose, cellobiose, melezitose, mannitol, sorbitol, inulin, salicin, and gluconate are not fermented. As with other bifidobacteria, glycerol, rhamnose, and lactate are not fermented.

End products from glucose fermentation. The molar ratio of lactic to acetic acid from the fermentation of glucose ranges from 1:4 (strain SU806) to 1:8 (strain SU882). $\mathrm{L}-(+)$-lactic acid is produced. Small amounts of formic acid are produced. Propionic and butyric acids are not produced.

Biochemical reactions. Catalase and pseudocatalase (hemin) are not produced; nitrate is not reduced; indole is not produced; acetylmethylcarbinol is produced; gelatin is not liquefied; skim milk is acidified and coagulated; ammonia is not produced from urea or arginine.

$\mathrm{G}+\mathrm{C}$ content of the DNA. The $\mathrm{G}+\mathrm{C}$ content of the DNA is $66.3 \pm 0.15 \mathrm{~mol} \%\left(\mathrm{~T}_{\mathrm{m}}\right)$.

DNA relationships. The DNA of this species is essentially unrelated to that of any other species or homology group of Bifidobacterium (homologies range from 10 to $30 \%$ ); exceptions are the DNAs of B. pseudolongum, B. globosum, and $B$. asteroides, for which the homologies range from 25 to $60 \%$.

Amino acid composition of the cell wall peptidoglycan. The interpeptide bridge of the murein of the cell wall of the type strain is Orn(Lys)-Ser-Ala ${ }_{2}$ (O. Kandler, personal communication).

Isozyme pattern. Transaldolase isozyme 3 and 6PGD (oxidized nicotinamide adenine dinucleotide phosphate dependent) isozyme 4 are displayed by all strains of the group tested. This 3-4 pattern is unique among the bifidobacteria.

Source. Feces of suckling piglets.

Type strain. The type strain is SU806 from the Collection of the Istituto di Microbiologia Agraria, Università di Bologna, Italy. A culture of this strain has been deposited in the American Type Culture Collection under the number 27686.

3. Bifidobacterium boum sp. nov. (bo' um. L. n. bos a cow; L. pl. gen. n. boum of cattle).

Cell characteristics. Gram-positive, nonmotile, nonsporeforming cells, 0.6 to 0.7 by 2.0 to $5.0 \mu \mathrm{m}$, very irregular in shape, generally occurring in pairs; the paired cells form wide angles, with protuberances, knobs, or branchings near the junction. Clumps of branched cells are frequent. Under slight anaerobiosis, extensive and complicated branching is frequent on cells with spatula-like extremities (see Fig. 3). The sediment in liquid TPY cultures is flaky or in mold-like pellets and is dispersed only with difficulty; the supernatant is clear.

Surface colonies (TPY medium). Smooth, convex, cream to white, glistening, and soft; entire edges.

Relationships to oxygen and $\mathrm{CO}_{2}$. Rather aerotolerant; grows in air $+\mathrm{CO}_{2} . \mathrm{CO}_{2}$ is not required for growth under anaerobic conditions.

Temperature relationships. Optimum, 39 to $40^{\circ} \mathrm{C}$; minimum, about $25^{\circ} \mathrm{C}$; maximum, about $45^{\circ} \mathrm{C}$; no growth at 20 or $46^{\circ} \mathrm{C}$.

pH relationships. Initial optimum $\mathrm{pH}$ is 6.5 to 7.0; growth is retarded at 6.0 or 7.4 ; no growth at 5.0 or 8.0 .

Fermentation pattern. Glucose, fructose, maltose, sucrose, melibiose, raffinose, starch, and dextrin are fermented. Arabinose, xylose, ribose, mannose, melezitose, sorbitol, mannitol, gluconate, glycerol, rhamnose, and lactate are not fermented. Lactose is fermented by $25 \%$ of the strains and cellobiose is fermented by $7 \%$; galactose is occasionally slowly fermented.

End products from glucose fermentation. The molar ratio of lactic to acetic acid from the fermentation of glucose is about 1:3. L-(+)-lactic acid is produced. Small amounts of formic acid are produced. Propionic and butyric acids are not produced.

Biochemical reactions. Catalase and pseudocatalase (hemin) are not produced; nitrate is not reduced; indole is not produced; acetylmethylcarbinol is produced; gelatin is not liquefied; skim milk is usually unchanged; ammonia is not produced from urea, asparagine, or arginine.

$\mathrm{G}+\mathrm{C}$ content of the DNA. The $\mathrm{G}+\mathrm{C}$ content of the DNA is $60.0 \pm 0.2 \mathrm{~mol} \%\left(\mathrm{~T}_{\mathrm{m}}\right)$.

DNA relationships. The DNA of this species is 60 to $70 \%$ related to that of $B$. thermophilum (B. ruminale) but is essentially unrelated to any other species (or homology group) of Bifidobacterium.

Amino acid composition of the cell wall peptidoglycan. The interpeptide bridge of the peptidoglycan of the cell wall of the type strain is Lys-Ser-Glu (O. Kandler, personal communication).

Isozyme pattern. Produces transaldolase isozyme 6. Also produces 6PGD (oxidized nicotinamide adenine dinucleotide phosphate dependent) isozymes 8,9 , and $9 \mathrm{a}$, which are shared by $B$. thermophilum (B. ruminale). The 6-8 pattern is shared by some $B$. suis strains.

Source. Rumen of cattle and feces of pigs; also found in sewage.

Type strain. The type strain is RU917 from the Collection of the Istituto di Microbiologia Agraria, Università di Bologna, Bologna, Italy. 
A culture of this strain has been deposited in the American Type Culture Collection under the number 27917.

4. Bifidobacterium pseudocatenulatum sp. nov. (pseu. do. ca. te. nu. la' tum. Gr. adj. pseudés false; L. adj. catenulatum specific epithet; M. L. adj. pseudocatenulatum the false [B.] catenulatum).

Cell characteristics. Gram-positive, non- motile, nonsporeforming, irregularly shaped rods, 0.6 to 0.7 by 2 to $5 \mu \mathrm{m}$, generally arranged in pairs which form angles with protuberances, knobs, or short branches near the point of contact. Strains with much more variable and irregular shape are occasionally found, including bifid forms similar to those of $B$. bifidum or pairs of cells with swollen ends similar to those of $B$. longum. Some strains show distorted chains of

TABLE 10. Fermentation patterns of B. pseudocatenulatum and B. catenulatum ${ }^{a}$ strains isolated from infant and calf feces and type strains ${ }^{b}$

\begin{tabular}{|c|c|c|c|c|c|}
\hline \multirow[b]{2}{*}{ Compound } & \multicolumn{3}{|c|}{ B. pseudocatenulatum } & \multicolumn{2}{|c|}{ B. catenulatum } \\
\hline & $\begin{array}{l}\text { From infant } \\
\text { feces } \\
100 \text { strains }\end{array}$ & $\begin{array}{l}\text { From calf } \\
\text { feces } \\
74 \text { strains }\end{array}$ & $\begin{array}{c}\text { Type strain } \\
\text { ATCC } 27919\end{array}$ & $\begin{array}{c}\text { From infant } \\
\text { feces } \\
37 \text { strains }\end{array}$ & $\begin{array}{c}\text { Type strain } \\
\text { ATCC } 27539\end{array}$ \\
\hline L-Arabinose & $+^{c}(97 / 100)^{d}$ & $+(74 / 74)$ & + & $+(36 / 37)^{d}$ & + \\
\hline D-Xylose & $+(98 / 100)^{e}$ & $+(74 / 74)$ & + & $+(32 / 37)^{e}$ & + \\
\hline D-Mannose & $+(68 / 100)^{f}$ & $+(53 / 74)^{\mathrm{f}}$ & + & $-(35 / 37)^{f}$ & - \\
\hline D-Cellobiose & $+(71 / 100)^{g}$ & $-(58 / 74)^{g}$ & + & $+(37 / 37)$ & + \\
\hline D-Trehalose & $+(76 / 100)^{f}$ & $-(41 / 74)^{f}$ & + & $+(21 / 37)^{f}$ & - \\
\hline Mannitol & $-(94 / 100)^{\mathrm{h}}$ & $-(73 / 74)^{h}$ & - & $-(31 / 37)^{h}$ & - \\
\hline Sorbitol & $+(100 / 100)$ & $+(39 / 74)^{\mathrm{i}}$ & + & $+(37 / 37)$ & + \\
\hline Salicin & $+(87 / 100)^{f}$ & $+(74 / 74)$ & + & $+(30 / 37)^{f}$ & + \\
\hline Inulin & $-(73 / 100)^{f}$ & $-(69 / 74)^{f}$ & - & $-(30 / 37)^{f}$ & - \\
\hline Starch & $+(100 / 100)$ & $+(74 / 74)$ & + & $-(37 / 37)$ & - \\
\hline Gluconate & $-(56 / 100)^{\mathrm{j}}$ & $-(74 / 74)$ & + & $-(24 / 37)^{j}$ & + \\
\hline
\end{tabular}

${ }^{a}$ The fermentation patterns of $B$. catenulatum strains from sewage and from feces of adult men were reported elsewhere (12). The pattern of the type strain B669 (=ATCC 27539) is reported here in its corrected version (see text).

${ }^{b}$ All strains fermented ribose, glucose, galactose, sucrose, maltose, lactose, melibiose, and raffinose. None fermented melezitose, rhamnose, glycerol, or lactate. Several strains of both species showed marginal or no fermentation of fructose (see footnote to Table 8).

c + , Fermented; - , not fermented.

${ }^{d}$ B. pseudocatenulatum: strains B2262, B2266, and B2351 were negative. B. catenulatum: strain B2124 was negative.

${ }^{e}$ B. pseudocatenulatum: strains B2263 and B2266 were negative. B. catenulatum: strains B2122, B2124, B2238, B2244, and B2245 were negative. The type strain, B669, occasionally fermented arabinose and xylose slowly (12).

${ }^{f}$ The behavior toward mannose, trehalose, salicin, and inulin is generally variable in most bifidobacteria; therefore the list of strains was omitted.

${ }^{g}$ B. pseudocatenulatum. From infants: strains B1280, B1286, B1297, B1330, B1830, B1831, B1832, B1833, B1834, B1886, B1888, B1965, B2067, B2247, B2248, B2249, B2250, B2251, B2252, B2253, B2262, B2263, B2266, B2340, B2351, B2362, B2363, B2366, and B2367 were negative. From calves: VT6, VT74, VT75, VT77, VT354, VT393, VT394, VT396, VT397, VT398, VT399, VT401, VT404, VT405, VT406, and VT409 were positive.

${ }^{h}$ B. pseudocatenulatum: From infants: strains B1828, B1830, B1831, B1832, B1833, and B1834 (all from the same specimen) were positive. From calves: strain VT9 was positive. B. catenulatum: strains B2238, B2241, B2242, B2243, B2244, and B2245 (all from the same specimen) were positive.

'B. pseudocatenulatum. From calves: strains VT6, VT9, VT74, VT75, VT184, VT201, VT202, VT203, VT204, VT205, VT206, VT207, VT254, VT262, VT263, VT265, VT269, VT270, VT337, VT339, VT341, VT348, VT351, VT353, VT354, VT356, VT360, VT368, VT369, VT370, VT371, VT372, VT373, VT374, and VT375 were negative.

'B. pseudocatenulatum: strains B1279, B1280, B1286, B1291, B1297, B1342, B1555, B1557, B1561, B1735, B1736, B1874, B1875, B1879, B1880, B1889, B1892, B1893, B1957, B1960, B1961, B1965, B1966, B1969, B1970, B1973, B1977, B2072, B2073, B2075, B2077, B2078, B2079, B2080, B2082, B2083, B2282, B2283, B2284, B2286, B2287, B2288, B2339, and B2445 were positive. B. catenulatum: strains B1331, B1333, B1334, B1338, B1340, $\mathrm{B} 1341, \mathrm{~B} 1738, \mathrm{~B} 1741, \mathrm{~B} 1742, \mathrm{~B} 1744, \mathrm{~B} 1745, \mathrm{~B} 1746$, and $\mathrm{B} 1748$ were positive. 
small coccoid and irregular cells or long, branched, hyphal-like cells (see Fig. 5).

Surface colonies (TPY medium). Smooth, convex, cream to white, glistening, and soft; entire edges.

Relationships to oxygen and $\mathrm{CO}_{2}$. Anaerobic. $\mathrm{CO}_{2}$ is without effect upon oxygen sensitivity or anaerobic growth.

Temperature relationships. Optimum, 39 to $41^{\circ} \mathrm{C}$; minimum, 28 to $29^{\circ} \mathrm{C}$; maximum, 42 to $43^{\circ} \mathrm{C}$; no growth at 26 or $44^{\circ} \mathrm{C}$.

pH relationships. Initial optimum $\mathrm{pH}$ is 6.5 to 6.9 ; growth is retarded at 6.0 or 7.2 ; no growth at 4.5 or 8.0 .

Fermentation pattern. Ribose, glucose, galactose, sucrose, maltose, lactose, starch, dextrin, melibiose, and raffinose are fermented. Melezitose, rhamnose, glycerol, and lactate are never fermented. Arabinose and xylose are fermented by most strains. Sorbitol is fermented by the strains isolated from feces of infants and by $50 \%$ of the isolates from calf feces. Gluconate is fermented by $45 \%$ of the strains from infants but not by those from calves. This pattern of fermented carbohydrates is shared by $B$. catenulatum which, however, does not ferment starch or dextrin (Table 10).

End products from glucose fermentation. The molar ratio of lactic to acetic acid from the fermentation of glucose is 1:2. L-(+)-lactic acid is produced. Large quantities of formic acid are produced. Propionic and butyric acids are not produced. $\mathrm{CO}_{2}$ is produced only in the fermentation of gluconate.

Biochemical reactions. Catalase and pseudocatalase (hemin) are not produced; nitrate is not reduced; indole is not produced; acetylmethylcarbinol is produced; gelatin is not liquefied; skim milk is acidified and coagulated; ammonia is not produced from urea, asparagine, or arginine.

$\mathrm{G}+\mathrm{C}$ content of the $\mathrm{DNA}$. The $\mathrm{G}+\mathrm{C}$ content of the DNA is $57.5 \pm 0.3 \mathrm{~mol} \%\left(\mathrm{~T}_{\mathrm{m}}\right)$.

DNA relationships. The DNA of this species is 60 to $80 \%$ related to that of $B$. catenulatum; it is essentially unrelated to that of any other species (or homology group) of Bifidobacterium.

Amino acid composition of the cell wall peptidoglycan. The interpeptide bridge of the peptidoglycan of the cell wall of the type strain is Lys-Ala $2_{2}$ Ser (O. Kandler, personal communication).

Isozyme pattern. Produces transaldolase isozyme 4; a few strains from calf feces produce isozyme 5; 6PGD (oxidized nicotinamide adenine dinucleotide phosphate dependent) isozymes 1 and 3 are produced; both 4-1 and 4-3 patterns are unique among the bifidobacteria and differ- entiate $B$. pseudocatenulatum from $B$. catenulatum, which has the 5-6 pattern.

Source. Abundant in sewage, in the feces of breast- and bottle-fed infants, and in the feces of suckling calves; found also in the feces of adult humans.

Type strain. The type strain is B1279 from the Collection of the Istituto di Microbiologia Agraria, Università di Bologna, Bologna, Italy. A culture of this strain has been deposited in the American Type Culture Collection under the number 27919.

\section{ACKNOWLEDGMENTS}

We are deeply grateful to 0 . Kandler, Botanisches Institut der Universität München, Munich, Germany, for having performed the cell-wall peptidoglycan analysis.

This investigation was supported by a research grant from the Consiglio Nazionale delle Ricerche, Roma.

\section{REPRINT REQUESTS}

Address reprint requests to: Dr. V. Scardovi, Istituto di Microbiologia Agraria, Università di Bologna, Bologna, Italy.

\section{LTTERATURE CITED}

1. Brenner, D. J. 1973. Deoxyribonucleic acid reassociation in the taxonomy of enteric bacteria. Int. J. Syst. Bacteriol. 23:298-307.

2. Crociani, F., V. Scardovi, and L. D. Trovatelli. 1970. Mannitol fermenting bifids from rumen and their DNA homology relationships. Ann. Microbiol. 20:99-106.

3. Johnson, J. L. 1973. Use of nucleic-acid homologies in the taxonomy of anaerobic bacteria. Int. J. Syst. Bacteriol. 23:308-315.

4. Kandler, O., and E. Lauer. 1974. Neuere Vorstellungen zur Taxonomie der Bifidobacterien. Zentralbl. Bakteriol. Parasitenkd. Infektionskr. Hyg. Abt. I Orig. 228: $29-45$.

5. Matteuzzi, D., F. Crociani, G. Zani, and L. D. Trovatelli. 1971. Bifidobacterium suis $\mathbf{n}$. sp.: a new species of the genus Bifidobacterium isolated from pig feces. Z. Allg. Mikrobiol. 11:387-395.

6. Mitsuoka, T. 1969. Vergleichende Untersuchungen über die Bifidobakterien aus dem Verdauungstrakt von Menschen und Tieren. Zentralbl. Bakteriol. Parasitenkd. Infektionskr. Hyg. Abt. I Orig. 210:52-64.

7. Palleroni, N. J., R. Kunisawa, R. Contopoulou, and M. Doudoroff. 1973. Nucleic acid homologies in the genus Pseudomonas. Int. J. Syst. Bacteriol. 23:333-339.

8. Reuter, G. 1963-64. Vergleichende Untersuchungen über die Bifidus-Flora im Saüglings- und Erwachsenenstuhl. Zentralbl. Bakteriol. Parasitenkd. Infektionkr. Hyg. Abt. I Orig. 191:486-507.

9. Reuter, G. 1971. Designation of type strains for Bifidobacterium species. Int. J. Syst. Bacteriol. 21:273-275

10. Rogosa, M. 1974. Genus III. Bifidobacterium Orla-Jensen, p. 669-676. In R. E. Buchanan and N. E. Gibbons (ed.), Bergey's manual of determinative bacteriology, 8 th ed. The Williams and Wilkins Co., Baltimore.

11. Scardovi, V., F. Casalicchio, and N. Vincenzi. 1979 Multiple electrophoretic forms of transaldolase and 6 phosphogluconic dehydrogenase and their relationships to the taxonomy and ecology of the bifidobacteria. Int J. Syst. Bacteriol. 29:312-327.

12. Scardovi, V., and F. Crociani. 1974. Bifidobacterium catenulatum, Bifidobacterium dentium, and Bifidobac- 
terium angulatum: three new species and their deoxyribonucleic acid homology relationships. Int. J. Syst. Bacteriol. 24:6-20.

13. Scardovi, V., and B. Sgorbati. 1974. Electrophoretic types of transaldolase, transketolase, and other enzymes in bifidobacteria. Antonie van Leeuwenhoek J. Microbiol. Serol. 40:427-440.

14. Scardovi, V., B. Sgorbati, and G. Zani. 1971. Starch gel electrophoresis of fructose-6-phosphate phosphoketolase in the genus Bifidobacterium. J. Bacteriol. 106: 1036-1039.

15. Scardovi, V., and L. D. Trovatelli. 1965. The fructose6-phosphate shunt as peculiar pattern of hexose degradation in the genus Bifidobacterium. Ann. Microbiol. 15:19-29.

16. Scardovi, V., and L. D. Trovatelli. 1969. New species of bifid bacteria from Apis mellifica $\mathrm{L}$. and Apis indica F. A contribution to the taxonomy and biochemistry of the genus Bifidobacterium. Zentralbl. Bakteriol. Parasitenkd. Infektionskr. Hyg. Abt. II 123:64-88.

17. Scardovi, V., and L. D. Trovatelli. 1974. Bifidobacterium animalis (Mitsuoka) comb. nov. and the "minimum" and "subtile" groups of new bifidobacteria found in sewage. Int. J. Syst. Bacteriol. 24:21-28.

18. Scardovi, V., L. D. Trovatelli, F. Crociani, and B. Sgorbati. 1969. Bifidobacteria in bovine rumen. New species of the genus Bifidobacterium: B. globosum $\mathbf{n}$. sp. and B. ruminale n. sp. Arch. Mikrobiol. 68:278-294.

19. Scardovi, V., L. D. Trovatelli, G. Zani, F. Crociani, and D. Matteuzzi. 1971. Deoxyribonucleic acid homology relationships among species of the genus Bifidobacterium. Int. J. Syst. Bacteriol. 21:276-294.

20. Scardovi, V., and G. Zani. 1974. Bifidobacterium magnum sp. nov., a large, acidophilic bifidobacterium isolated from rabbit feces. Int. J. Syst. Bacteriol. 24:2934.

21. Scardovi, V., G. Zani, and L. D. Trovatelli. 1970. Deoxyribonucleic acid homology among the species of the genus Bifidobacterium isolated from animals. Arch. Mikrobiol. 72:318-325.

22. Sgorbati, B., G. Lenaz, and F. Casalicchio. 1976. Purification and properties of two fructose-6-phosphate phosphoketolases in Bifidobacterium. Antonie van Leeuwenhoek J. Microbiol. Serol. 42:49-57.

23. Staley, T. E., and R. R. Colwell. 1973. Deoxyribonucleic acid reassociation among members of the genus Vibrio. Int. J. Syst. Bacteriol. 23:316-332.

24. Trovatelli, L. D., F. Crociani, M. Pedinotti, and V. Scardovi. 1974. Bifidobacterium pullorum sp. nov.: a new species isolated from chicken feces and a related group of bifidobacteria isolated from rabbit feces. Arch. Mikrobiol. 98:187-198.

25. Trovatelli, L. D., and D. Matteuzzi. 1976. On the presence of bifidobacteria in the rumen of calves fed different rations. Appl. Environ. Microbiol. 32:470-473.

26. Zani, G., B. Biavati, F. Crociani, and D. Matteuzzi. 1974. Bifidobacteria from the faeces of piglets. J. Appl. Bacteriol. 37:537-547. 